\title{
A semântica do eufemismo: mineração e tragédia em Brumadinho
}

\section{Euphemism semantics: mining and tragedy in Brumadinho La semántica del eufemismo: minería y tragedia en Brumadinho}

\author{
Valdir de Castro Oliveira ${ }^{1, a}$ \\ valdirco@yahoo.com.br | https://orcid.org/o0oo-0001-6104-9746 \\ Daniela de Castro Oliveira ${ }^{2, b}$ \\ danicastro91@gmail.com | https://orcid.org/o00o-0003-3028-4262
}

\footnotetext{
${ }^{1}$ Fundação Oswaldo Cruz, Instituto de Comunicação e Informação Científica e Tecnológica em Saúde, Programa de Pós-Graduação em Comunicação e Informação para a Saúde. Rio de Janeiro, RJ, Brasil.

2 Sem vínculo institucional.

a Doutorado em Ciências da Comunicação pela Universidade de São Paulo.

• Graduação em Comunicação Social (Relações Públicas) pela Pontifícia Universidade Católica de Minas Gerais.
}

\section{Resumo}

Esta nota de conjuntura consiste numa análise das peças comunicacionais produzidas pela Vale e circuladas na região do Vale do Paraopeba, que engloba os municípios de Congonhas, Belo Vale e Brumadinho. O material analisado foi distribuído em 2018 após o desastre causado por essa empresa no município de Mariana (MG). No estudo, estabelecemos a hipótese de que a construção da imagem pública da Vale diante do ocorrido em Mariana e o recente desastre em Brumadinho (MG) esteve baseada na semântica do eufemismo, uma modalidade discursiva que privilegia a imagem idealizada pela empresa sobre si mesma. Além de apontar uma mudança dos atuais modelos de desenvolvimento econômico, é necessário rever os modelos informacionais e comunicacionais que não promovam o efetivo diálogo social. O texto ainda apresenta um testemunho do impacto do rompimento da barragem sobre a população de Brumadinho e região e as danosas e dramáticas consequências para a sociedade e o meio ambiente.

Palavras-chave: Comunicação; Discurso; Desastres; Diálogo; Mineração, Brumadinho; Brasil.

\begin{abstract}
This note is an analysis of the communication produced by the global mining company Vale and circulated in the Paraopeba Valley's region, which includes the municipalities of Congonhas, Belo Vale and Brumadinho. The material analyzed was distributed in 2018 after the disaster caused by Vale in the municipality of Mariana (MG). In the study, it was hypothesized the construction of the public image of Vale in front of the Mariana and the recent disaster in Brumadinho (MG) was based on the euphemism
\end{abstract}


semantics, a speech modality which favours the image idealized by the company about itself. Besides highlighting a change in current models of economic development, it is necessary to review informational and communication models that do not promote effective social dialogue. The text also shows a statement of the impact of the dam rupture on the population of Brumadinho and its region and the damaging and dramatic consequences for society and the environment.

Keywords: Communication; Speech; Disasters; Dialogue; Mining, Brumadinho; Brazil.

\section{Resumen}

Esta nota de coyuntura consiste en un análisis de las piezas comunicacionales producidas por la empresa global de minería Vale y circuladas en la región del Valle del Paraopeba, que engloba los municipios de Congonhas, Belo Vale y Brumadinho. El material analizado fue distribuido en 2018 tras el desastre causado por esa empresa en el municipio de Mariana (MG). En el estudio, establecimos la hipótesis de que la construcción de la imagen pública de la Vale ante lo ocurrido en Mariana y el reciente desastre en Brumadinho (MG) estuvo basada en la semántica del eufemismo, una modalidad discursiva que privilegia la imagen idealizada por la empresa sobre sí misma. Además de apuntar un cambio de los actuales modelos de desarrollo económico, es necesario revisar los modelos informativos y comunicacionales que no promuevan el efectivo diálogo social. El texto también presenta un testimonio del impacto del rompimiento de la represa sobre la población de Brumadinho y región y los daños y dramáticas consecuencias para la sociedad y el medio ambiente.

Palabras clave: Comunicación; Discurso; Desastres; Diálogo; Minería, Brumadinho; Brasil.

Contribuição dos autores:

Concepção e desenho do estudo: Valdir de Castro Oliveira.

Aquisição, análise ou interpretação dos dados: Valdir de Castro Oliveira e Daniela de Castro Oliveira.

Redação do manuscrito: Valdir de Castro Oliveira.

Revisão crítica do conteúdo intelectual: Valdir de Castro Oliveira.

Declaração de conflito de interesses: não há.

Fontes de financiamento: não houve.

Considerações éticas: não há.

Agradecimentos/Contribuições adicionais: não há.

Histórico do artigo: submetido: 18 mar. 2019 | aceito: 20 mar. 2019 | publicado: 31 mar. 2019.

Apresentação anterior: Texto utilizado pelo primeiro autor como debatedor da aula inaugural do ensino do Instituto de Comunicação e Informação Científica e Tecnológica em Saúde (Icict) da Fundação Oswaldo Cruz (Fiocruz), realizada no dia 19 de março de 2019 no salão de leitura da Biblioteca de Manguinhos, Fiocruz, Rio de Janeiro. Tema da aula: "O modelo de desenvolvimento brasileiro e a produção de desastres. A perspectiva da informação e comunicação". Palestrante: Carlos Vainer (Instituto de Pesquisa e Planejamento Urbano Regional - IPPUR/Universidade Federal do Rio de Janeiro); debatedores: Eliane Lima e Silva (Laboratório de Geografia, Ambiente e Saúde - Lagas/Universidade de Brasília) e Valdir de Castro Oliveira (Programa de PósGraduação em Comunicação e Informação para a Saúde - PPGICS/Icict).

Licença CC BY-NC atribuição não comercial. Com essa licença é permitido acessar, baixar (download), copiar, imprimir, compartilhar, reutilizar e distribuir os artigos, desde que para uso não comercial e com a citação da fonte, conferindo os devidos créditos de autoria e menção à Reciis. Nesses casos, nenhuma permissão é necessária por parte dos autores ou dos editores. 


\section{De Mariana a Brumadinho}

A lama que escorreu depois do rompimento da barragem de rejeitos da mineradora San Marco, associada a Vale, em Mariana (MG), no dia 5 de novembro de 2015, uma quinta-feira, foi considerada na época o maior desastre ambiental do Brasil. Calcula-se terem sido derramados cerca de 50 a 60 milhões de metros cúbicos dessa lama que destruiu o distrito de Bento Rodrigues, além de afetar Águas Claras, Ponte do Gama, Paracatu e Pedras e cerca de 40 cidades localizadas na Bacia do Rio Doce em Minas Gerais e no Espírito Santo.

Além de matar 19 pessoas, essa lama afetou drasticamente a vida e a economia da região, assim como sua fauna e flora, tornando as águas do Rio Doce impróprias para o consumo humano em muitas das cidades afetadas.

Mas o mais dramático é constatar que os atingidos por esta tragédia, como os moradores de Bento Rodrigues e Paracatu de Baixo, da comunidade de Gesteira, no município de Barra Longa, que tiveram suas casas destruídas e foram obrigados a deixar suas comunidades, após três anos ainda não tiveram suas casas reconstruídas e nenhuma família foi reassentada. Segundo o Movimento dos Atingidos pelas Barragens (MAB), as empresas envolvidas dificultam ao máximo as negociações provocando o desânimo dos atingidos ou levando-os a desistir dos seus direitos aceitando a oferta rebaixada de indenização proposta pela Fundação Renova, criada pelas empresas para cuidar das consequências da tragédia. ${ }^{1}$

Quatro anos depois, no dia 25 de janeiro, uma sexta-feira, a cidade de Brumadinho, separada por cerca de 80 quilômetros de distância de Mariana, também testemunhou e sofreu tragédia similar quando a barragem de rejeitos da mina do Córrego do Feijão, também explorada pela Vale, derramou cerca de 11,7 milhões de metros cúbicos de lama com alto teor de silício e ferro no leito do córrego Ferro e Carvão. Além de matar centenas de pessoas, essa lama soterrou tudo o que encontrou pela frente, destruindo plantações, vidas e os sonhos das pessoas que estavam em seu caminhoi.

Em ambas as tragédias estavam diretamente envolvidas o mesmo setor econômico (mineração) e a mesma empresa, a Vale, deixando no ar publicamente a pergunta se a primeira tragédia não teria servido de lição para evitar a segunda ou outras tragédias similares nesse setor?

Ao que tudo indica e, conforme reconhecido publicamente pelo próprio ex-presidente da Vale logo após a tragédia de Brumadinho, a empresa tirou pouco proveito dessa lição.

Entretanto, não se pode dizer que entre uma e outra tragédia nada foi feito pela empresa.

Na região do Vale do Paraopeba, onde a empresa tem forte atuação, principalmente nos municípios de Congonhas, Belo Vale e Brumadinho, logo depois da tragédia de Mariana, constataram-se, publicamente, duas ordens de preocupação: uma primeira de ordem relacional em que a Vale tenta interagir com a população e as lideranças comunitárias nesses municípios, apoiando e valorizando histórias e projetos locais e outra, relacionada com a segurança, principalmente, das suas barragens de rejeitos.

Tais preocupações manifestaram-se, principalmente, através de várias edições do boletim da Vale postos em circulação nos municípios do Vale do Paraopeba. Nos boletins, revelam-se as preocupações da empresa com a segurança das barragens e o envolvimento das populações locais e de seus empregados nessa questão.

Na maioria das edições às quais tivemos acesso, a preocupação central estampada era com as várias barragens de rejeitos mantidas pela empresa na região e com ações preventivas e cuidados - que tanto a empresa quanto a população deveriam ter para evitar acidentes - ou sobre como agir em caso de rompimento de alguma dessas barragens.

\footnotetext{
i A barragem B1 da Mina do Feijão foi construída em 1976 pela Ferteco Mineração, que pertencia ao grupo alemão Thyssen Krupp Stahl, e foi adquirida pela Vale em 27 de abril de 2001. A estrutura tinha 87 metros de altura e foi alteada pelo método a montante, o mesmo da barragem de Fundão, em Mariana. Em julho de 2016, as operações de beneficiamento do minério no local passaram a ser realizadas a seco. A partir daí a barragem deixou de receber rejeitos, o que não evitou a tragédia sem precedentes.
} 
Analisando esses boletins, observamos que o processo de comunicação pretendido pela empresa esteve muito mais baseado em um modelo informacional do que comunicacional e fortemente centrado no emissor. Nesse modelo disponibilizam-se as informações que este julga ser relevante para o público sem se preocupar com a questão da mediação ou com aquilo que Eliseo Verón² chama de semiose infinita, na qual o conteúdo e os processos de interação entre os interlocutores são contínua e dialeticamente alterados gerando novos signos e símbolos. Ao contrário disso, o emissor julga que a simples disponibilidade informacional encerra o processo comunicacional estabelecido entre a empresa e os potenciais públicos a quem se dirige.

Ademais, observamos também que as informações funcionam muito mais como uma espécie de peças promocionais voltadas para a construção de uma imagem positiva da empresa com a finalidade de aumentar o seu coeficiente de credibilidade junto aos seus potenciais públicos que residem nesses municípios.

Essas estratégias comunicacionais estão relacionadas com as premissas desenvolvidas pelo sociólogo Anthony Giddens ${ }^{3}$ segundo as quais o padrão da vida moderna exige que tenhamos uma expectativa compartilhada baseada em modelos de confiança abstrata (fora das lealdades do quadro familiar) em que devemos depositar nossa confiança. Sem essa confiança a vida e a cooperação social se tornariam impossíveis de acontecer. A resposta sistêmica a esta questão é o que ele chamou de sistemas peritos que seriam conformados por profissionais que, amparados em conhecimentos técnicos, incrementam a lógica de funcionamento da sociedade moderna. Por exemplo, se não sabemos dirigir um avião, depositamos nossa confiança no piloto e sua equipe, certos de que eles corresponderão às nossas expectativas de nos levar com segurança de um lugar para outro; quando nos sentimentos mal, procuramos um médico; quando vamos construir ou reformar um prédio contrata-se uma equipe de engenheiros e, se queremos construir ou atestar a segurança de uma barragem, procuramos peritos credenciados para este mister já que como leigos pouco sabemos a respeito desses assuntos.

Sem um grau mínimo de confiança nesses sistemas peritos e seus respectivos profissionais, o mundo moderno ficaria paralisado. O problema, tal qual vivenciamos hoje no nosso sistema político, é quando essa confiança é rompida; é quando testemunhamos constantemente quedas de avião, desabamentos de pontes e prédios, mortes frequentes em hospitais, ou, neste caso, rompimento de barragens.

A junção desses acontecimentos nos leva a desconfiar dos sistemas peritos e, simultaneamente, das empresas ou instituições que, depois de situações como as que aconteceram em Mariana e Brumadinho, por eles se responsabilizam e/ou os abrigam. Em vista disso, começamos a nos questionar, por exemplo: você confia na Vale?ii

Está implícita nessa pergunta a imagem objetiva e subjetiva que temos ou possamos ter dessa empresa, ainda que, neste momento, mesmo que de forma difusa, saibamos a resposta negativa para essa questão.

Isto nos leva a perguntar de que maneira a Vale vinha construindo a sua imagem e que mensagens e valores faz circular publicamente na construção do seu ethos corporativo, principalmente diante daquilo que hoje mais a fragiliza que é segurança, a preservação ambiental e a interação dialógica que se propõe a manter com as comunidades instaladas no entorno das suas unidades de produção, como é o caso de Mariana, Congonhas, Belo Vale e Brumadinho, onde ocorreu o rompimento de duas das dezenas de barragem de rejeitos que mantém na região.

O nosso pressuposto para entender esse processo é o fato de o discurso de representação simbólica que conforma o ethos de uma determinada organização ser constituído a partir das representações sociais reais e imaginárias que julgamos ser positivamente compartilhadas por uma sociedade ou parte dela, envolvendo

ii A mineradora é responsável pela maior parte da extração e comercialização de minério de ferro no Brasil. Conhecida dos brasileiros desde a década de 1940 como Companhia Vale do Rio Doce, a estatal foi privatizada em 1997, e a partir de 2007 alterou seu nome e logomarca para Vale S.A. No seu sítio eletrônico, a missão da empresa é "transformar recursos naturais em prosperidade e desenvolvimento sustentável", com a visão de "ser a empresa de recursos naturais global número um em criação de valor de longo prazo, com excelência, paixão pelas pessoas e pelo planeta". Disponível em: http://www.vale.com/brasil/PT/ aboutvale/mission/Paginas/default.aspx 
valores, estereótipos ou outras formas de representação social. A construção desse ethos mobiliza diferentes recursos comunicacionais em conformidade com a importância que a organização atribui a determinados princípios e valores sociais que devem ser codificados simbolicamente para seus pretensos públicos. Isso nos leva a considerar que as organizações ou as corporações modernas sempre partem do pressuposto de que não devem ser identificadas apenas pelo setor de atividades que desenvolvem, mas fundamentalmente pelas complexas construções discursivas que fazem para serem entendidas como portadoras de valores sociais e simbólicos valorados positivamente pela sociedade. ${ }^{4}$

Dessa maneira, a empresa ou corporação transforma as enunciações institucionais em discursos destacando aqueles que consideram relevantes para identificar as potencialidades que julgam merecer junto ao(s) público(s) ou que possam trazer algum retorno positivo em relação a sua imagem pública. ${ }^{4}$

O problema é que essas organizações estão situadas em territórios tensionados por diferentes valores e constelações discursivas da sociedade que nem sempre correspondem à imagem ou ao ethos por elas projetados e desejados, situações que diminuem o seu coeficiente de credibilidade frente aos diferentes setores da opinião pública que se manifestam ou possam vir a se manifestar na esfera pública.

Situações inesperadas, como as tragédias de Mariana e de Brumadinho abalam os alicerces desse tipo de edifício simbólico construído pelas organizações, aumentando a distância entre o que acontece na realidade e as práticas discursivas que elas desenvolvem. Tais eventos comprometem não apenas a sua imagem nos mercados em que atuam, mas também em relação aos públicos com os quais interage ou que pretende influenciar.

Quando aconteceram as duas tragédias anteriormente mencionadas, a credibilidade da empresa se mostrou bastante abalada e nos fez perguntar com que ingredientes ela vinha construindo e ainda constrói o seu ethos frente à opinião pública e como interage com os públicos das regiões em que desenvolve suas atividades?

Analisando o comportamento da empresa e parte do material de comunicação por ela publicamente disponibilizado, estabelecemos a hipótese aqui de que a construção do seu ethos ou imagem pública empreendida antes e durante estas duas tragédias, esteve baseado no que estamos chamando aqui de semântica do eufemismo, ou seja, uma modalidade discursiva sustentada por declarações, comunicados, textos e ilustrações na qual se reitera mais a imagem idealizada pela empresa sobre si mesma do que o resultado dos processos de interação que desenvolve ou se propõe a desenvolver com a sociedade, modulando signos, símbolos e palavras de ordem e de maneira a coincidirem com as expectativas e os valores politicamente corretos e desejáveis pela opinião pública. Nessa modalidade discursiva, a imagem da empresa se apresenta sempre como uma organização responsável, compromissada com valores sociais, justiça social, sustentabilidade e, principalmente, com segurança, embora nem sempre esses valores sejam totalmente compartilhados pelos seus públicos e, em muitos casos, possam inclusive ser contestados por diferentes setores da sociedade mediante práticas contradiscursivas.

Ainda assim, essa contestação não impede ou inibe a empresa de continuar a investir fortemente na comunicação para aumentar, dessa maneira, o seu grau de confiança junto a diferentes públicos. Ao produzir vários tipos de peças comunicacionais que, em seu conjunto, devem ser capazes de reforçar tanto a sua marca no mercado quanto a contribuição de seus produtos para criar e manter o elevado padrão e conforto de que desfruta a sociedade moderna. A empresa destaca, paralelamente, os compromissos éticos que declara ter em relação ao meio ambiente, a segurança e a sociedade.

É desse lugar que a empresa procura também incrementar suas práticas diretas de relacionamento com as comunidades que vivem no entorno das suas unidades produtivas, além de estabelecer intensivos contatos com as estruturas de poder representadas pelos órgãos do Estado ou da sociedade civil com a finalidade de amenizar as crescentes formas de resistência e contestação de suas atividades em determinados territórios.

São por essas razões também que a Vale e outros atores do setor de mineração vêm, nos últimos anos, redirecionando suas estratégias de comunicação, buscando eufemisticamente realçar seus compromissos 
com o conceito de sustentabilidade, de preservação ambiental, de geração de empregos e riquezas para a sociedade. Tais compromissos são ou devem ser sempre calcados em valores éticos.

Uma breve análise sobre as bem montadas e criativas peças comunicacionais produzidas pela Vale sob o título de 'Somos redescobridores' nos mostra como, discursivamente, a empresa faz de modo ostensivo a defesa de suas atividades e as relaciona sempre com valores éticos e de respeito ao meio ambiente e à natureza. Por meio delas, a Vale se propõe a interagir dialogicamente com diferentes e potenciais públicos, seja aqueles que conformam uma opinião pública difusa, seja aqueles que vivem no entorno onde desenvolvem suas atividades principais.

O conjunto dessas peças comunicacionais, que circulam intensivamente em todo o Brasil através da mídia e das redes sociais, tenta nos convencer de que, apesar dos problemas e dos impactos que as atividades de mineração provocam ao meio ambiente, são elas que garantem o conforto da sociedade moderna e que, para assim continuar a existir dessa maneira, delas depende.

Enfim, há muito que se investigar para sabermos como esses empreendimentos, diante das adversidades e de uma atitude hostil de certos setores da opinião pública, fazem ressignificar discursivamente suas estratégias de comunicação, particularmente quando são instados a se confrontar com os movimentos ambientalistas, os movimentos sociais e comunitários e organizações públicas e privadas que questionam a natureza de suas atividades com base nos conceitos de sustentabilidade e defesa do meio ambiente ou daqueles que simplesmente se queixam e agem contra os impactos provocados nos locais onde esses empreendimentos atuam.

Em resposta a alguns questionamentos da sociedade, a série 'Somos redescobridores' também reitera a ideia subjacente de que não existe nada no mundo que não possa ser repensado e/ou redescoberto. Ao associar a ideia de reinventar o futuro com a atividade mineradora, a série propõe que o enxerguemos de outra forma, a fim de que seja possível reconhecer que o principal objetivo da Vale seria o de 'entregar minério de alta qualidade' e garantir o princípio da sustentabilidade.

No vídeo, que foi ao ar inicialmente ${ }^{\mathrm{iii}}$ em agosto de 2018, a mensagem central era a de que "as redescobertas estão melhorando o mundo" e que "redescobrir é a nossa natureza”. Declarações como essas foram transformadas em lemas que se associam à ideia de que a Vale está melhorando o mundo.

As peças comunicacionais em formato de boletins que foram distribuídas no circuito minerador do Vale do Paraopeba - em que se inclui Brumadinho - entre 2017 e 2018, ou seja, após a tragédia de Mariana também constituem material relevante para análise. Em um deles, a Vale reitera e enaltece as "vidas em constante transformação"5 e o apoio que a empresa dá a jovens esportistas da cidade de Brumadinho através da intitulada 'Estação Conhecimento' por ela mantida na cidade. No informe, enfatiza o depoimento positivo sobre a mudança de vida dos jovens atendidos com o fato de que "outras 720 crianças e adolescentes entre 6 e 18 anos, vêm tendo a oportunidade de buscar novos caminhos por meio do esporte. Com o suporte da Estação Conhecimento, os jovens preenchem o contra turno escolar com atividades socioeducativas como o esporte, trabalhado nas modalidades futebol, atletismo e natação". ${ }^{5}$

A seguir, no mesmo boletim em que divulga notícias sobre o Festival de Inverno de Congonhas e destaca atividades culturais que patrocina nesse município, a Vale informa também que "no início de julho reunimos especialistas e representantes das defesas civis dos municípios próximos às nossas barragens para discutir a

iii No vídeo inicial de apresentação da estratégia de comunicação Redescobridores, o conteúdo foi apresentado a fim de justificar o adjetivo 'redescobridores'. O primeiro episódio que foi ao ar, com a duração de 30 segundos, tinha como argumento o fato de a empresa possuir uma reserva natural, onde preserva a Mata Atlântica e protege a biodiversidade local. Até o momento, a campanha teve ao todo cinco episódios. Todos os vídeos da campanha foram acessados em 2018, quando ainda estavam disponíveis no endereço http://www.vale.com/brasil/pt/aboutvale/redescobridores/paginas/default.aspx. Atualmente, o conteúdo encontra-se indisponível para acesso, o que pode ser considerado um erro na nomeação atual do endereço ou ainda a remoção do conteúdo da página da empresa 
importância do engajamento da comunidade na construção de uma cultura de prevenção e autoproteção" e, ainda informa a realização de simulados de "emergência de barragens". ${ }^{5}$

Ainda em outro boletim a Vale faz a seguinte pergunta ao leitor: "Você sabe a importância das barragens na mineração?”. Em seguida, explica que elas são estruturas onde é depositado o material que não será utilizado, além de armazenar a "água que é recirculada nas usinas, contribuindo para operações mais sustentáveis". ${ }^{6}$

Em outro boletim reitera a importância que a empresa atribui à preservação ambiental com o título 'Verde que te quero verde'8 por meio do apoio dado a projetos de preservação ambiental e de sustentabilidade promovidos pelas escolas do município de Belo Vale "através do Concurso Escolas Sustentáveis em que promove hortas comunitárias"8, destacando quatro escolas que participam deste projeto.

Em outro boletim é destacado o depoimento de uma pedagoga (Maria Aparecida) sobre a barragem de rejeitos de Congonhas: "Eu tinha uma ideia muito ruim do que era uma barragem, mas nunca tinha chegado perto de uma. Depois da visita que eu fiz a Vale concluí que é um trabalho muito bem feito e inteligente". ${ }^{8}$

Segundo a Vale, essa pedagoga resume o sentimento dos moradores de Congonhas que visitaram a Mina Fábrica com um grupo de 33 associados e familiares da Associação dos Aposentados, Pensionistas e idosos da Cidade (Asapec). ${ }^{8}$

No depoimento antecedido pelo subtítulo 'Segurança garantida'8, se informa que os "parâmetros de segurança das barragens também chamaram a atenção de Maria Aparecida, que perdeu o receio que tinha antes da visita. 'Achei muito interessante o processo de filtragem que é feito na água, para retorná-la limpa à natureza. Também vi como é realizado o monitoramento dos recursos naturais e entendi que é um processo bem seguro"”. ${ }^{8}$

Já na contracapa de outro boletim (Figura 1) é destacado que "Treinamento também é prevenção" . Conforme publicado no corpo da matéria, "para agir corretamente em uma situação de emergência é preciso conhecimento. Por isso a Vale, em parceria com a Defesa Civil, começou a realizar exercícios simulados nas comunidades próximas às suas barragens" 9 . A empresa informa ainda que, durante esses exercícios, foram "testados recursos, rotas de fuga e pontos de encontro das localidades previstos nos Planos de ação de Emergência de Barragens de Mineração (PAEMMs)" e que, no dia 22 de julho, foi feito "um simulado nas comunidades Moreira e Boa Morte, em Belo Vale, que contou com a participação de 50 pessoas, o que corresponde a 70\% dos moradores”. 9 


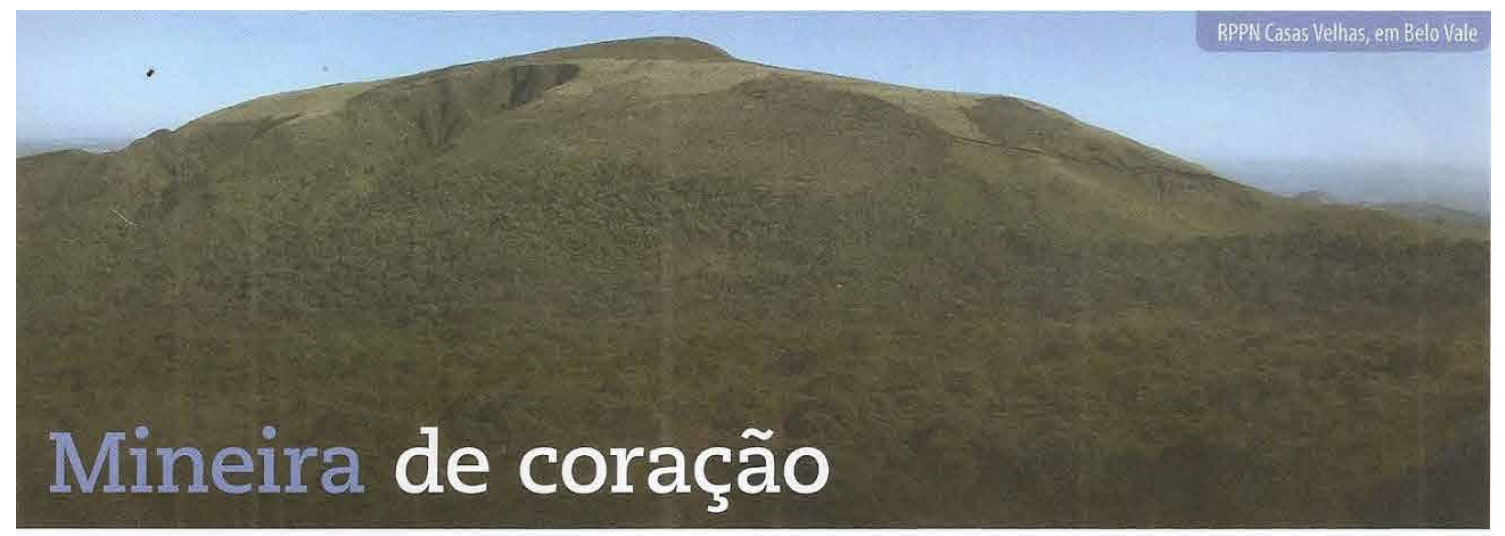

P Minas Gerais - A Vale é uma das maiores mineradoras do mundo. E o orgulho de ter nascido em terras mineiras é vivenciado diariamente. Prova disso são os investimentos que a empresa realiza no desenvolvimento socioeconômico das comunidades onde mantém suas operações, bem como na preservação do meio ambiente. Todas essas iniciativas estão contempladas no relatório A Vale em Minas Gerais 2017, que você confere em www.vale.com. Veja aqui alguns destaques.

Gestão Ambiental - O volume de área preservada pela Vale no Quadrilátero Ferrfero é cerca de 3,5: vezes maior do que a area minerada por ela. Săo 68.377 hectares de áreas protegidas. So nas reservas de Poço Fundo, em Congonhas; Casas Velhas, em Belo Vale: Mata do Jequitibá, em Brumadinho; e Tumbá e Mata do Jambreiro, em Nova Lima; săo, aproximadamente, 1.600 hectares de área.

\section{Treinamento também é prevenção}

P Minas Gerais - Para agir corretamente em uma situação de emergência é preciso conhecimento. Por isso, a Vale, em parceria com a Defesa Civil, começou a realizar exercícios simulados nas comunidades próximas às suas barragens. Durante a atividade, são testados recursos, rotas de fuga e pontos de encontro das localidades previstos nos Planos de Ação de Emergência de Barragens de Mineração (PAEBMs).

No dia 22 de julho, realizamos um simulado nas comunidades Moreira e Boa Morte, em Belo Vale, que contou com a participação de 50 pessoas, o que corresponde a quase $70 \%$ dos moradores.

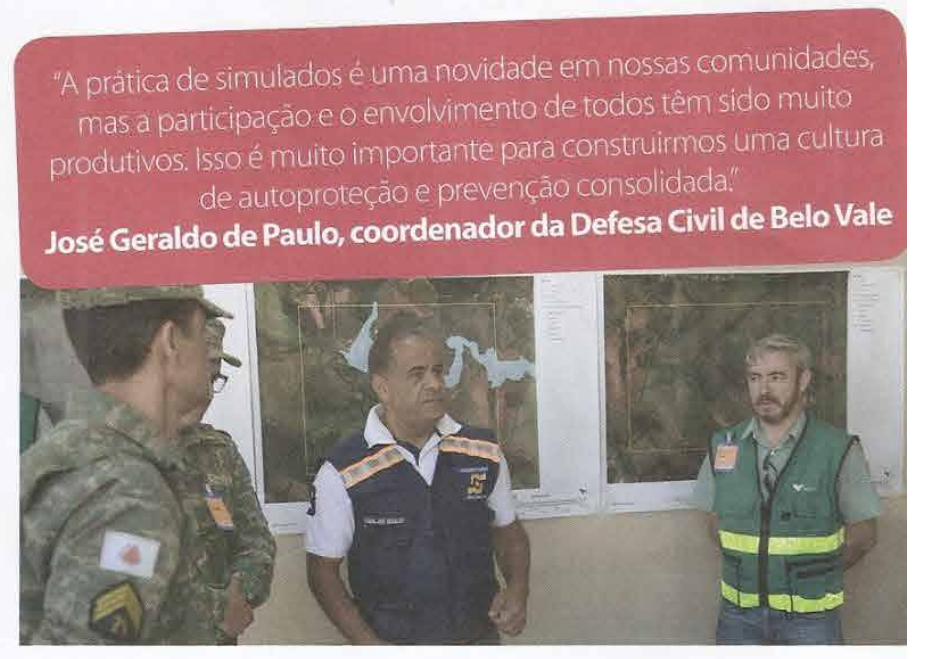

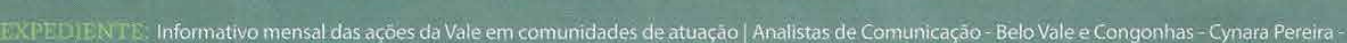

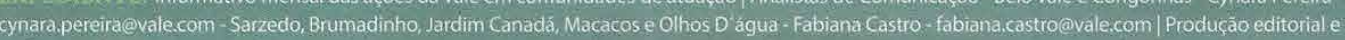

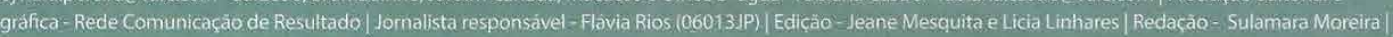
Diagramaçâ- Ingrid Siuves | Tiragem - 2 mil exemplares | Para mais informaçoes acesse: www.vale.com

Figura 1 - Notícias Vale: treinamento também é prevenção

Fonte: Vale (2018). ${ }^{9}$ 
Ao final da matéria, a Vale interpela os leitores para conhecer a unidade da Mina Fábrica disponibilizando o endereço do site para agendamento de visitas.

Em outra edição deste mesmo boletim produzido em novembro de 2018, a Vale informa que possui 111 barragens distribuídas em 17 municípios mineiros onde atua e que "10o\% delas têm atestado de estabilidade garantida, conforme auditoria externa finalizada em setembro deste ano (2018)"ro,iv (o grifo é nosso).

Embora esse boletim tenha sido publicado depois do rompimento da barragem do Fundão em Mariana, a Vale afirma que em "76 anos de história, a Vale não possui histórico de acidentes em suas barragens" (o grifo é nosso). O boletim foi publicado em novembro de 2018 e, dois meses depois, em janeiro de 2019, ocorre o rompimento da barragem em Brumadinho.

$\mathrm{Na}$ contracapa desse boletim, a Vale interpela os seus leitores indagando-os se já ouviram falar no Plano de Ação de Emergência de Barragens (PAEBM), um documento padrão do setor de mineração com orientações específicas sobre prevenção para casos de emergência. ${ }^{10}$

A seguir, explica o que a Vale tem feito a respeito deste Plano de Emergência com base em quatro variáveis: (1) cadastro, no qual informa que $100 \%$ das comunidades que se encontram nas áreas denominadas como autossalvamento foram abordadas para cadastros; (2) realização de sete simulados com 80\% de adesão, abrangendo 1,3 mil pessoas nos treinamentos e previsão, até junho de 2019, da instalação de 221 sirenes; (3) implantação, até outubro de 2019, de 74\% dessas sirenes; (4) realização de encontros técnicos, em parceria com as defesas civis, para discussão e troca de experiências relacionadas à cultura de prevenção. Informa ainda que, ao longo de três anos, cerca de 400 pessoas estiveram presentes e a iniciativa teve $98 \%$ de avaliação positiva entre os participantes desses encontros. ${ }^{10}$

iv Segundo dados do Plano de Segurança de Barragens, da Agência Nacional de Águas, existem 114 barragens de rejeitos em todo o Quadrilátero Ferrífero, mais 104 estruturas não cadastradas no Plano, entre barragens, diques, gabiões. Essas estruturas decorrem da exploração mineral na região, especialmente ferro, ouro, argila e gemas. Deste total, o dano potencial associado (dano ocasional caso ocorra uma ruptura) é alto para 70 deles e baixo apenas para 12. Em caso de rupturas as Bacias do Rio Doce, Rio das Velhas, Paraopeba e Rio Pará serão as mais prejudicadas. Além das barragens, existem ainda 56 minas paralisadas e abandonadas no Quadrilátero Ferrífero. ${ }^{1}$ 


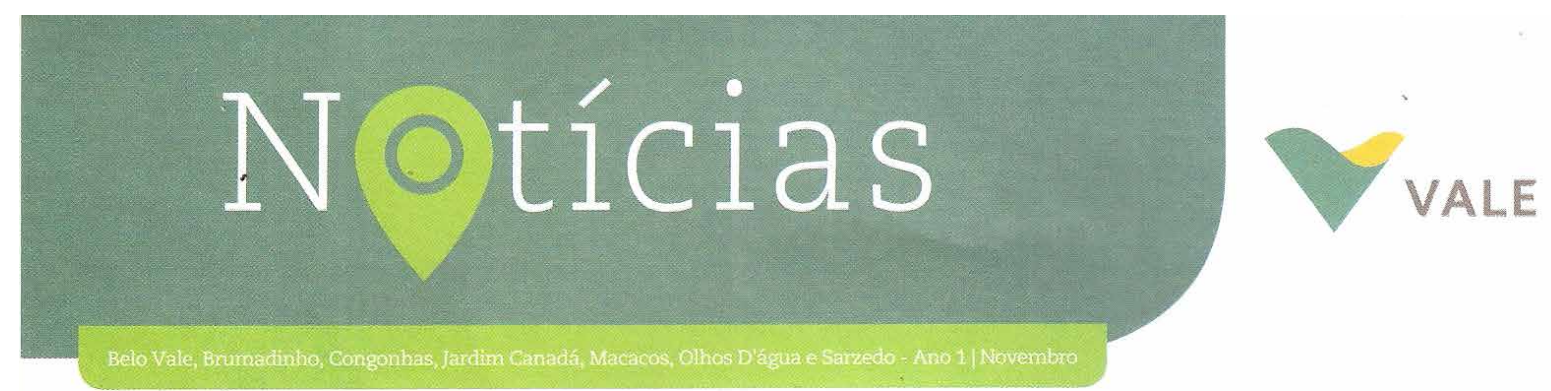

\section{Responsabilidade com a segurança}

P Minas Gerais - Em 76 anos de trajetória, a Vale não possui histórico de acidentes em suas barragens. Com o total de 111 barragens distribuídas em 17 municipios mineiros onde a empresa atua, 100\% delas têm atestado de estabilidade garantida, conforme auditoria externa finalizada em setembro deste ano.

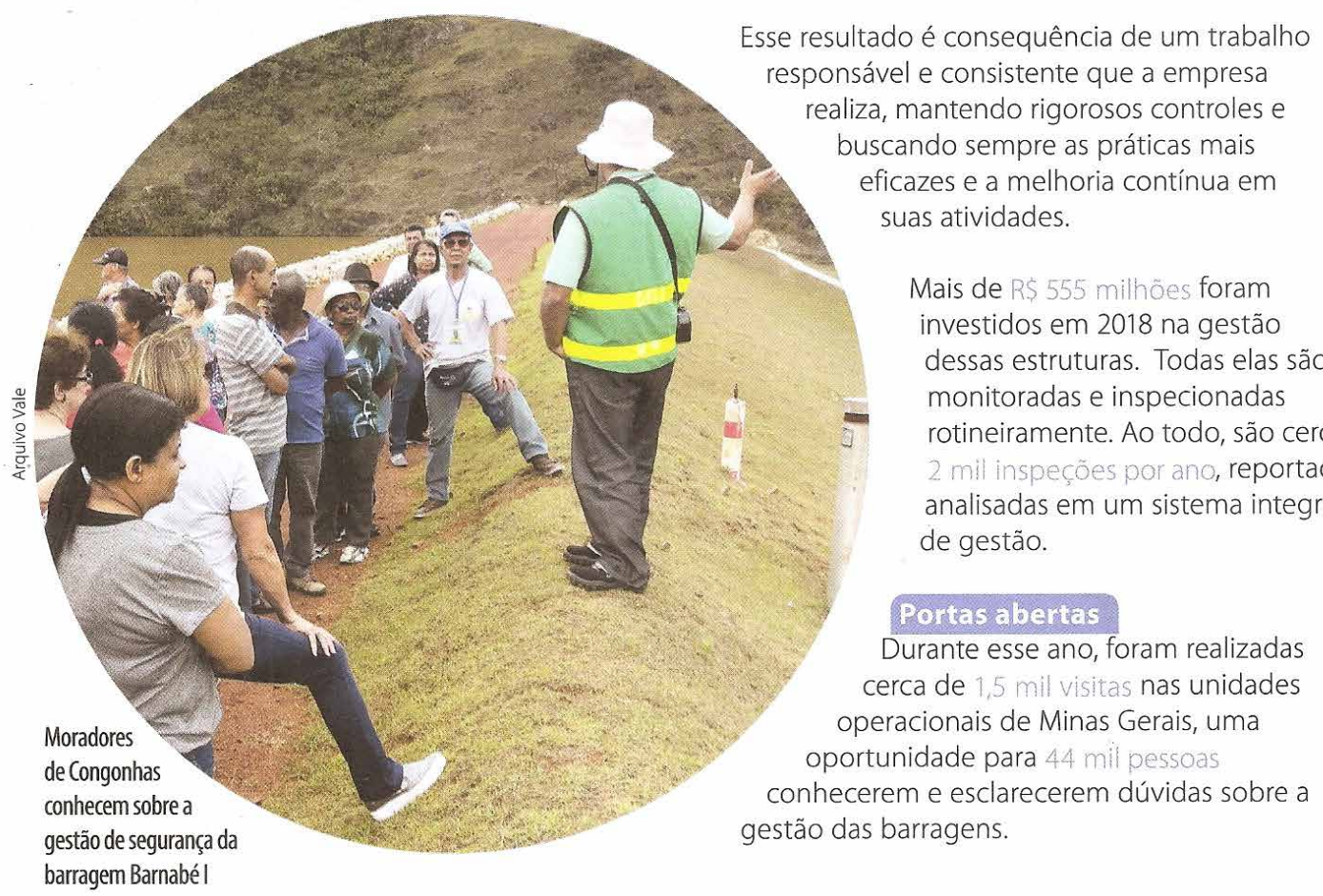

Figura 2 - Notícias Vale: responsabilidade com segurança Fonte: Vale $(2018)^{10}$

Em seguida, invoca os testemunhos de três empregados da Vale, acompanhados de suas respectivas fotografias, que reiteram os cuidados que a empresa dedica à segurança. O primeiro depoimento é feito pelo Chefe de Segurança de Belo Vale: "mesmo quem não mora nas áreas de autossalvamento está empenhado em participar dos simulados, pois também pode ajudar outras pessoas caso aconteça qualquer situação de emergência. Isso comprova a abrangência das ações e a preocupação da empresa com a segurança de todos” ${ }^{10}$ (o grifo é nosso).

No segundo depoimento, o gerente de Operações e Manutenção da Mina Fábrica afirma que "é importante que os moradores conheçam os procedimentos de segurança para que possam se antecipar em alguma situação de emergência. Os simulados são fundamentais para preparar a comunidade e disseminar uma cultura de prevenção". ${ }^{10}$ 
O terceiro depoimento é de uma moradora de Brumadinho (Lecilda Oliveira), que trabalhava na Vale há 30 anos desde a época da Ferteco. Ela ocupava o cargo de analista de operações, função que conseguiu depois de passar por várias promoções na empresa. No boletim, Lecilda enfatiza a postura responsável da mineradora: "o monitoramento de suas barragens, junto aos exercícios de simulados, possibilita que empregados e comunidade se sintam mais seguros e preparados para proceder em caso de emergência. Estar bem informado e orientado é imprescindível para fortalecer a cultura de prontidão" ${ }^{\prime \prime}$ (o grifo é nosso). Esse boletim foi publicado em novembro do ano passado pela companhia, ou seja, dois meses antes da tragédia da Vale em Brumadinho.

A estratégia discursiva desses depoimentos está baseada na credibilidade e na popularidade das fontes que o compõem, como no caso de Lecilda, que era uma pessoa muito popular e querida tanto pelos outros funcionários na Vale quanto na cidade de Brumadinho e, por isso mesmo carinhosamente chamada por todos de 'Lecilda da Vale'.

\section{A tragédia em Brumadinho}

Apesar de todo o aparato e cuidados com a segurança, as informações de mobilização popular e de treinamento da população em caso de rompimento de barragens, a reiteração sobre a segurança das barragens da empresa em todo o Vale do Paraopeba, nada disso impediu que ocorresse o rompimento da barragem de rejeitos da Mina do Córrego do Feijão, em Brumadinho, no dia 25 de janeiro, uma sexta-feira.

Dois dias depois, dia 27/01, às 5h30, na cidade de Brumadinho, as sirenas de alarme, que não tocaram no dia da tragédia, tocaram. Bombeiros e voluntários desesperados anunciavam que outra barragem, essa de água, próxima à do Córrego do Feijão havia sido rompida e que moradores próximos ao centro deveriam evacuar a cidade.

Em seguida, foi anunciado o bloqueio da ponte do Rio Paraopeba que liga Brumadinho a Belo Horizonte.

Segundo a Defesa Civil, o rompimento da barragem causaria prejuízo ainda pior do que aquele provocado pela lama da barragem de rejeitos, uma vez que a água desceria com mais velocidade e atingiria áreas urbanas da cidade, represando a curva do Rio Paraopeba e inundando os bairros próximos e o centro da cidade - tal como sempre acontece durante os períodos chuvosos mais fortes. Isso deixou a população mais tensa do que já estava.

Ao contrário do que apregoavam as publicações da mineradora em circulação no Vale do Paraopeba, a população não estava preparada e sequer informada sobre esse esquema de alarme e de emergência, o que casou pânico aos moradores. Afinal de contas, as informações constantes nos boletins da Vale distribuídos em várias cidades declaravam que todas as suas barragens eram seguras e periodicamente monitoradas, vistoriadas e fiscalizadas pela própria Vale e por empresas de consultoria externa.

Ainda que de forma confusa, felizmente, no dia 27/01, não demorou a chegar a notícia de que a barragem estava estável e sem perigo de rompimento; o acionamento havia sido apenas um teste. A Defesa Civil de Brumadinho, em resposta, declarou que não foi avisada desse teste.

Se por um lado foi positivo saber que esse sistema de alarme funcionou na cidade, por outro lado foi chocante constatar que o sistema similar instalado no principal local da tragédia não tenha funcionado quando aconteceu o rompimento da barragem de rejeitos do Córrego do Feijão, o que fez com que os funcionários efetivos e terceirizados da empresa e visitantes que se encontravam no restaurante e no setor administrativo ficassem sem chance de escapar.

Somente após essa tragédia é que as pessoas passaram a se perguntar: por que razão havia um restaurante e várias instalações administrativas bem abaixo da barragem?

E se perguntavam também: e o tal Plano de Emergência informado no Boletim da Vale?

Por que não funcionou? 
Talvez nem mesmo a antiga funcionária e moradora de Brumadinho, Lecilda Oliveira, que depôs a favor da segurança da empresa no Boletim da Vale que circulou em novembro de 2018, soubesse explicar, pois dois meses depois ela seria mais uma da lista de centenas de vítimas desta tragédia cujo corpo permanece desaparecido até o presente momento, como anunciou Raul Mariano no informativo Interesse de Minas no dia $15 / 03 / 2019 .{ }^{11}$

Como se tudo isso não bastasse, a população teve de conviver ainda com um incompetente sistema informativo e comunicativo da empresa que, ao invés de informar e levar tranquilidade às pessoas, acabou esgotando mais ainda a paciência dos familiares que perderam algum ente querido nesta tragédia anunciada. Os canais indicados pela empresa funcionavam precariamente e, quando alguém conseguia acioná-los, recebia informações desencontradas e um atendimento pouco condizente com a dramaticidade da situação, não obstante a boa vontade dos seus funcionários e das autoridades públicas.

Ademais, os notórios e frequentes desencontros entre a empresa, as autoridades e a Defesa Civil fizeram com que centenas de voluntários que se ofereciam para ajudar fossem secamente dispensados. Em muitos momentos, o comando das operações ora se apresentava concentrado nos Bombeiros, ora na Polícia Militar, ora se apresentava pulverizado entre a Defesa Civil do Estado e do Município, enquanto a Vale pouco aparecia nesse cenário.

Só aos poucos e depois de muitos desencontros e superação de muitos ruídos informacionais é que a organização do socorro aos atingidos pelo rompimento da barragem foi ganhando consistência, mas sem eliminar ainda completamente o desconforto provocado pelos fluxos desinformativos vitimando, principalmente, as centenas de familiares das pessoas desaparecidas ou mortas que corriam desesperadamente atrás de qualquer migalha informacional capaz de ajudá-los na localização de seus parentes, vizinhos ou amigos vitimados por esta tragédia. Como baratas tontas, trançavam entre o Instituto Médico Legal, o Pronto-Socorro João XXIII e outros hospitais de Belo Horizonte e, de posse de alguma informação, seguiam para o local na esperança de ter notícias de seus entes queridos. Quando lá chegavam, nada encontravam e retornavam cansadas e frustradas para Brumadinho.

A sensação que se tinha era a de que os representantes da Vale não se encontravam em nenhum lugar ou que tenham optado por uma atuação tão discreta que se tornaram praticamente invisíveis aos olhos da população, ao contrário das caríssimas peças publicitárias da empresa, como as da série 'Somos Redescobridores' que circulam no Brasil e que, sem nenhuma cerimônia, adentra aos lares brasileiros através da televisão, da internet e dos telefones dos usuários da telefonia celular nas quais a empresa emerge como amiga extremada da sustentabilidade, da segurança, da cultura e do desenvolvimento social. 


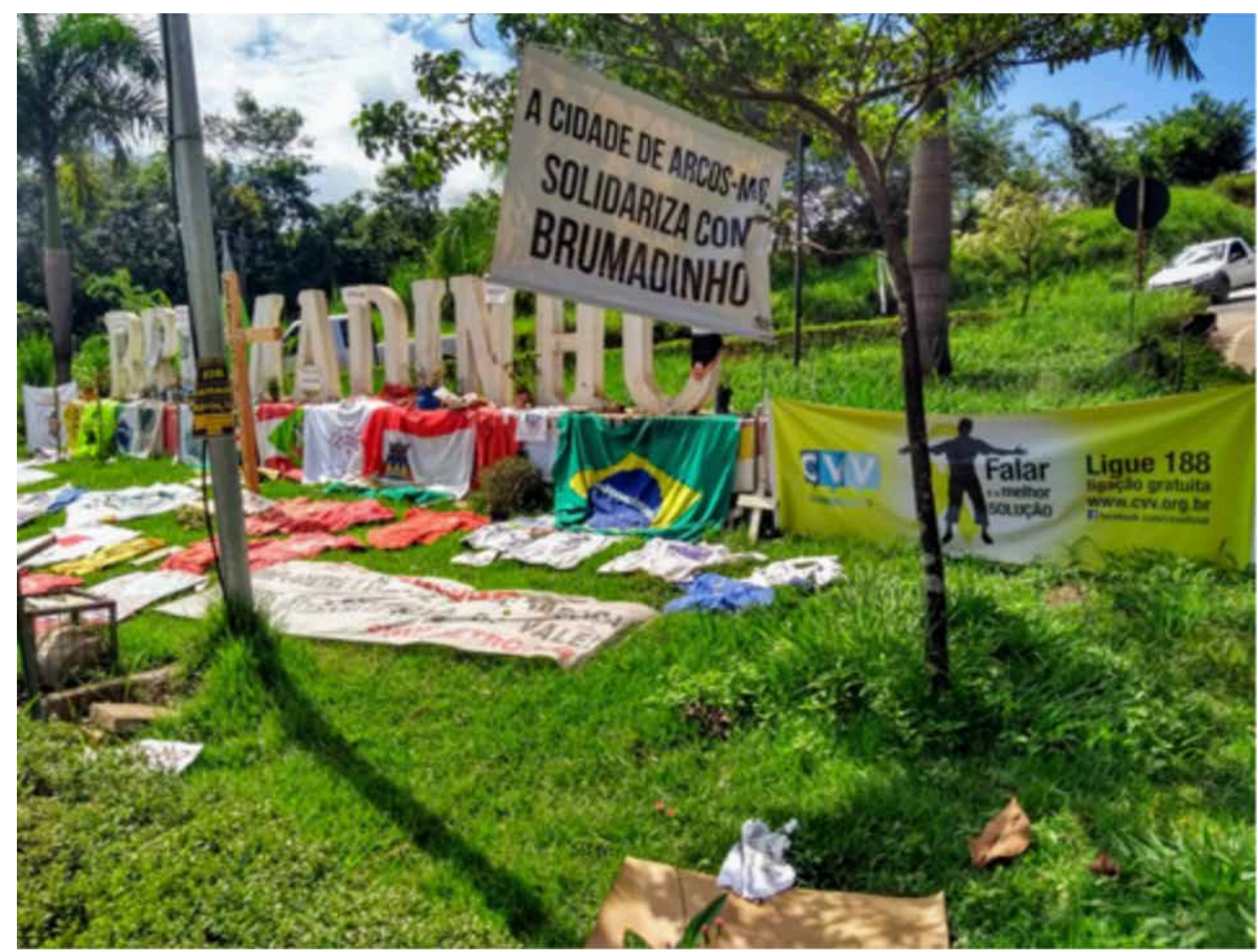

Figura 3 - Solidariedade popular representada pelas roupas e bandeiras de quem atuou nos dramáticos resgates durante a tragédia provocada pela Vale em Brumadinho

Fonte: Valdir de Castro Oliveira (2019).

A duras penas e indescritível sofrimento, algumas pessoas conseguiram lutar e sobreviver graças ao providencial socorro e solidariedade de amigos, vizinhos ou dos soldados do Corpo de Bombeiros, auxiliados pela Polícia Militar, Polícia Civil e diferentes órgãos da sociedade civil que também se atolaram nesta lama para salvar pessoas e animais. Nesse mister, voluntários de muitos estados brasileiros, de vários países, do Estado e do Município foram exemplares no socorro às vítimas.

Após uma semana do rompimento da barragem de rejeitos, chuvas torrenciais caíram em Brumadinho fazendo com que a lama que rompeu da barragem de rejeitos escorresse devagarzinho até encontrar o Rio Paraopeba. Suas águas amareladas se tingiram de vermelho da cor de sangue e ficaram impróprias para o consumo humano. Foram inviabilizados os serviços de captação de águas nesse rio para abastecimento de grandes cidades, como Pará de Minas e Belo Horizonte. Por essa mesma razão, centenas de agricultores tiveram de cruzar os braços, por ficarem impedidos de irrigar suas plantações e por terem ficado sem horizonte para o exercício de outras atividades.

Até este momento (18/03) foram contabilizados nesta tragédia 206 mortos e 102 desaparecidos, além dos incalculáveis prejuízos ambientais, financeiros e morais para a população e o município. Houve ainda a destruição de cerca de 133 hectares de vegetação nativa de mata atlântica e 71 hectares de área de preservação permanente. Um número incalculável de animais domésticos ou selvagens pertencentes à fauna local também ficaram presos ou morreram nesta lama. 


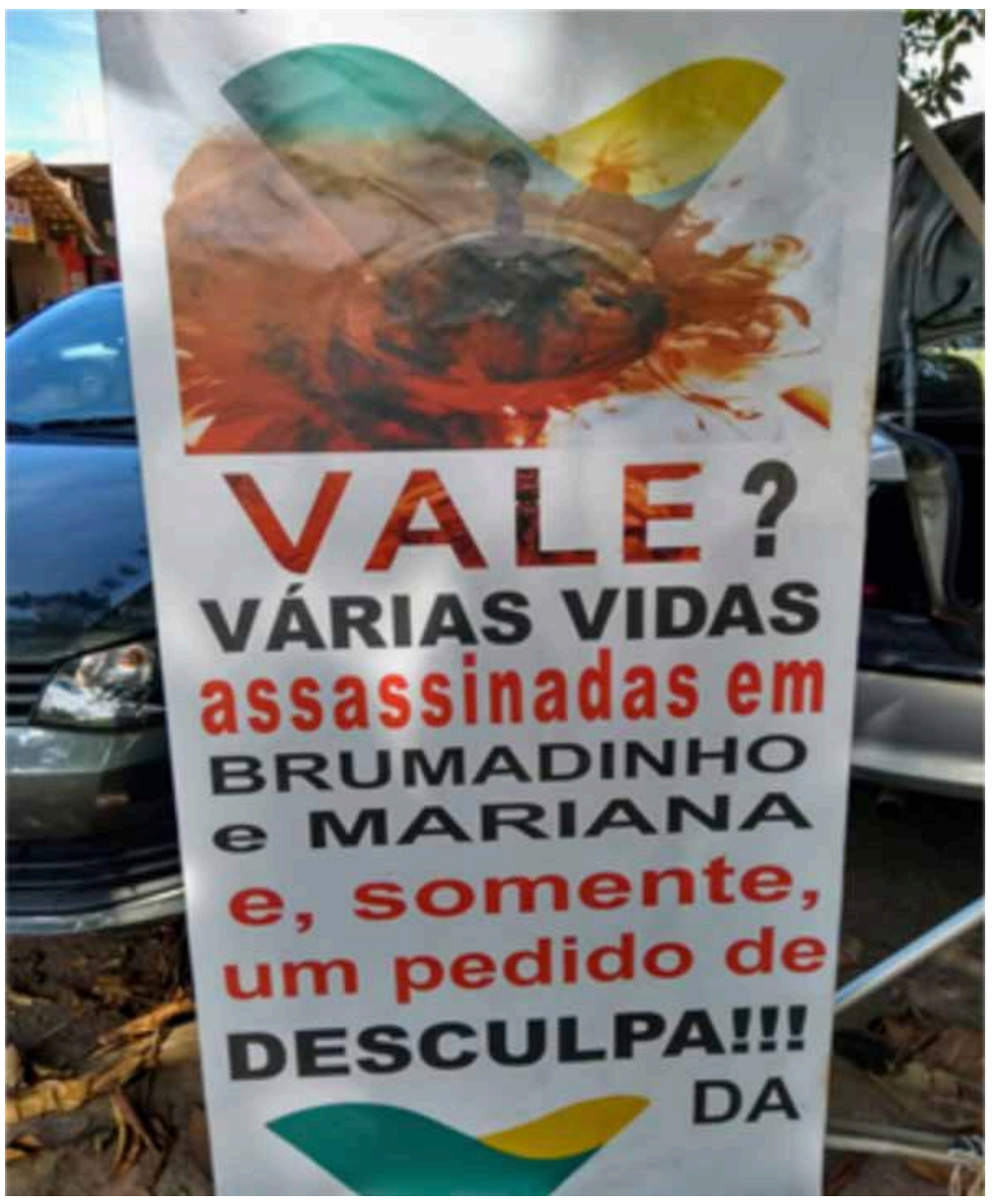

Figura 4 - Vidas assassinadas se satisfazem com um pedido de desculpa? Fonte: Valdir de Castro Oliveira (2019).

Quanto à qualidade das águas do Rio Paraopeba, a SOS Mata Atlântica a classificou como péssima ou ruim nos 22 pontos de coleta que montou no rio. Foram encontrados nelas metais pesados, como manganês, cromo e cobre, além de bactérias comuns em cemitérios e aterros sanitários. ${ }^{12}$

A rápida circulação e o impacto de informações a esse respeito afetaram também muitos agricultores, que, mesmo usando água limpa para a irrigação de seus produtos, tiveram suas mercadorias recusadas na Ceasa de Belo Horizonte pelo simples fato de serem originárias de Brumadinho.

As escolas, que se preparavam para a volta das aulas, adiaram o início do semestre letivo; restaurantes e pousadas tiveram de aceitar os pedidos de cancelamento de suas reservas por causa do acontecido.

Para agravar a situação, a estrada de acesso a Alberto Flores e Córrego do Feijão foi interditada dificultando o ir e vir de centenas de moradores locais. 


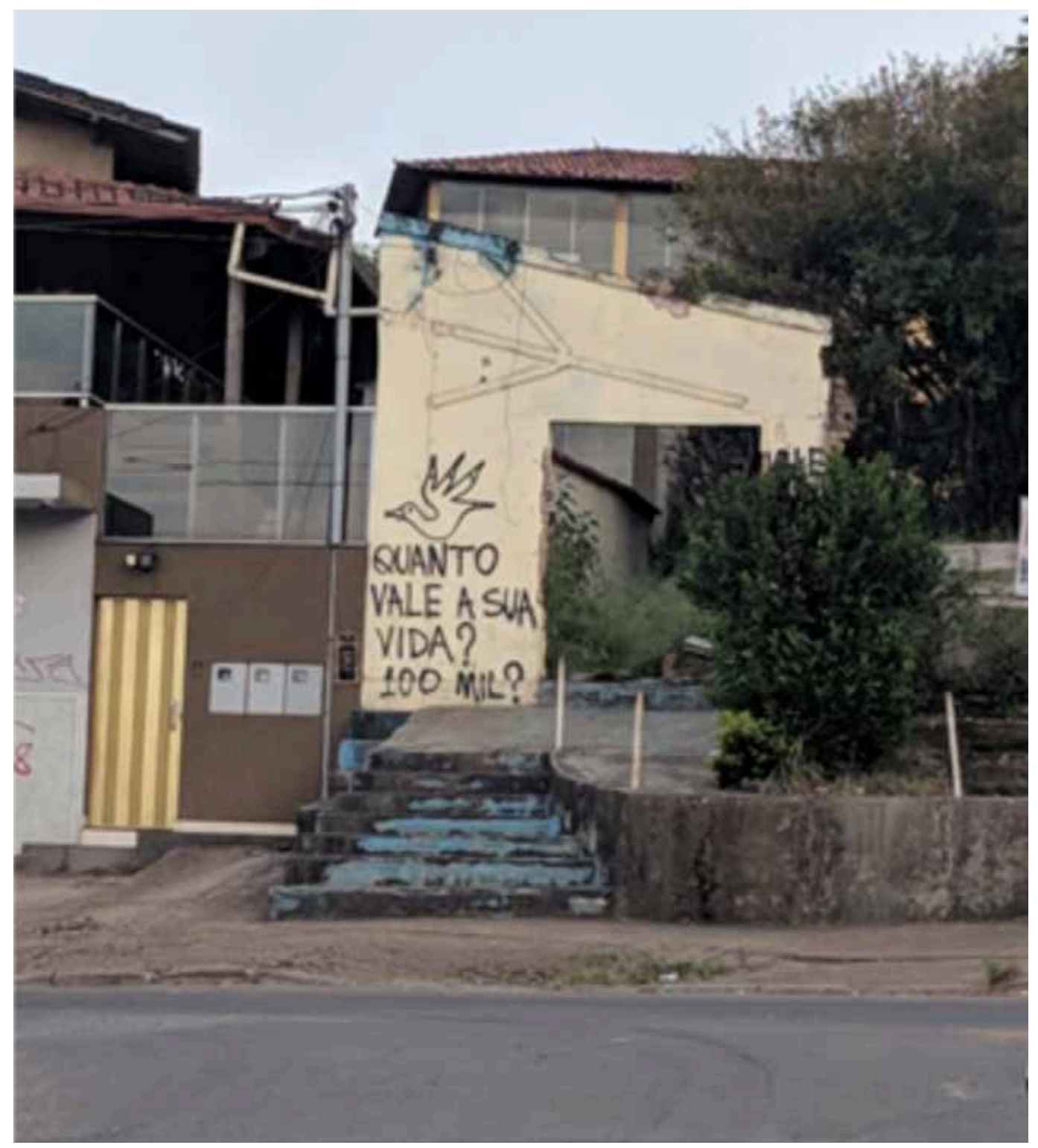

Figura 5 - Quanto Vale a vida? Fonte: Júlia Crosman (2019).

Nas semanas seguintes ao rompimento da barragem, do ar só se ouvia o zunir insistente dos helicópteros que sobrevoavam a zona do desastre em busca de sobreviventes ou de corpos. De vez em quando, uma dessas aeronaves passava em voo rasante carregando corpos resgatados no perímetro da tragédia levando-os para o campo de futebol da comunidade do Córrego do Feijão, onde os bombeiros montaram sua principal base de operação de salvamento. Era dali que os corpos seguiam diretamente para o Instituto Médico Legal em Belo Horizonte sob o olhar sofrido de parentes e amigos que se aglomeravam desesperados no alambrado da cerca que isolava o local querendo informações sobre a identidade das vítimas.

Em Brumadinho, o silêncio da pequena e pacata cidade era quebrado várias vezes ao dia pelos acordes das Bachianas brasileiras, de Villa Lobos, que funcionava como uma senha a anunciar o nome de mais uma vítima e convidar os parentes e amigos para as celebrações fúnebres, dando a ela o seu último adeus antes de ser enterrada em um dos cemitérios municipais - cena que se repetia quase que diariamente também nos povoados e distritos.

A convergência desses quadros dava a impressão de que a vida havia sido cancelada, deixando a morte reinar soberana em Brumadinho. 


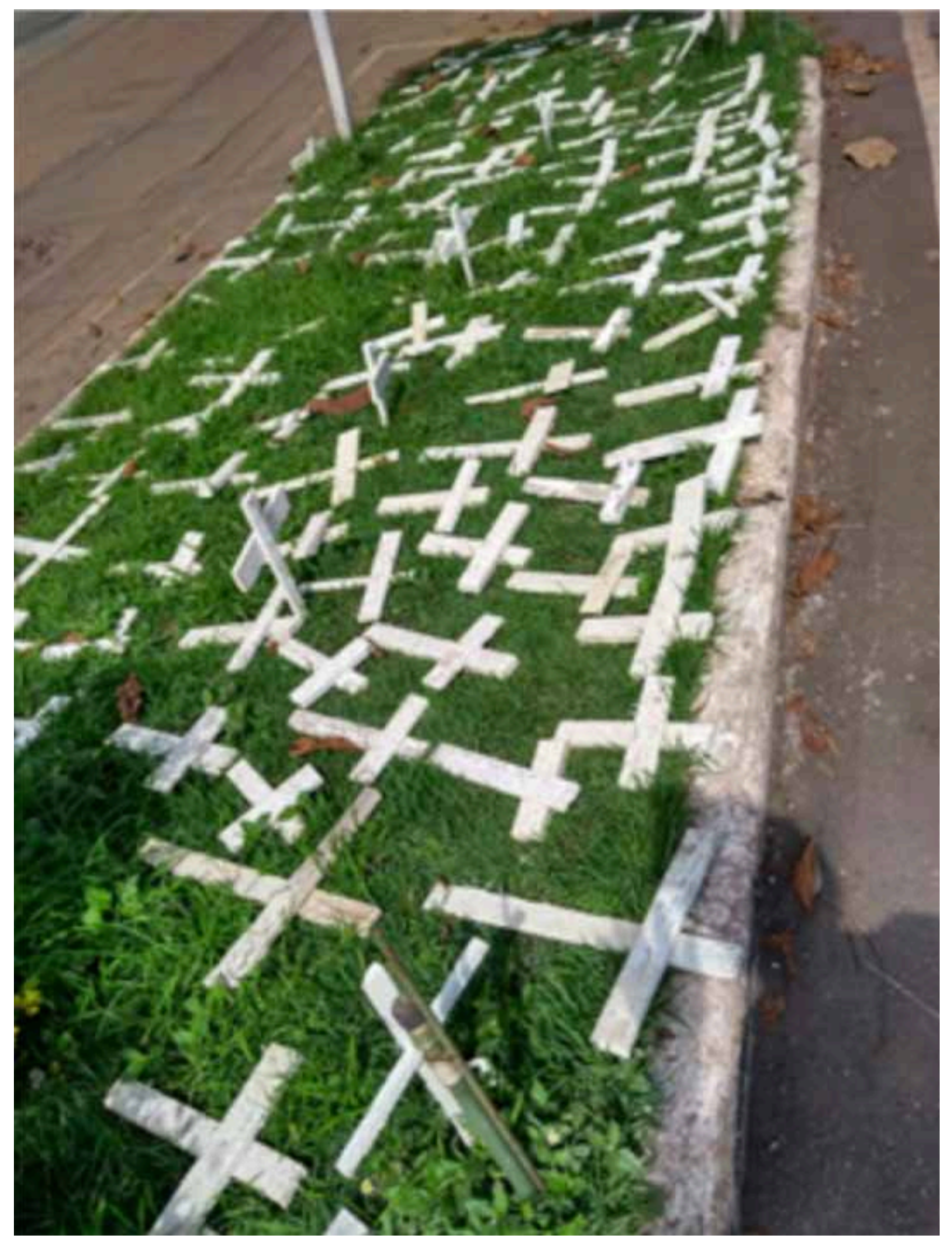

Figura 6 - Cruzes na entrada da cidade simbolizam as vítimas do rompimento da barragem da Vale em Brumadinho Fonte: Valdir de Castro Oliveira (2019)

Apesar de todos esses transtornos e sofrimento, foi reconfortante saber que o Sistema Único de Saúde (SUS) local tinha mobilizado todo o seu efetivo municipal e, contando também com a inestimável ajuda do SUS metropolitano e estadual, pôde atender exemplarmente as demandas na área de saúde que se multiplicaram exponencialmente nesse período, principalmente no campo da urgência e emergência, envolvendo tanto a assistência médica quanto psicossocial que tinham de dar conta das centenas de pessoas feridas, doentes ou mentalmente desnorteadas por essa tragédia. Por causa disso, todos os médicos, enfermeiros, auxiliares de enfermagem, motoristas, viaturas e demais profissionais ligados a assistência básica, a saúde mental e a vigilância sanitária foram mobilizados, ficando em permanente estado de prontidão para atender os diferentes casos que surgiam a cada momento e, simultaneamente, manter em funcionamento a rotina dos outros serviços de saúde prestados à população. 


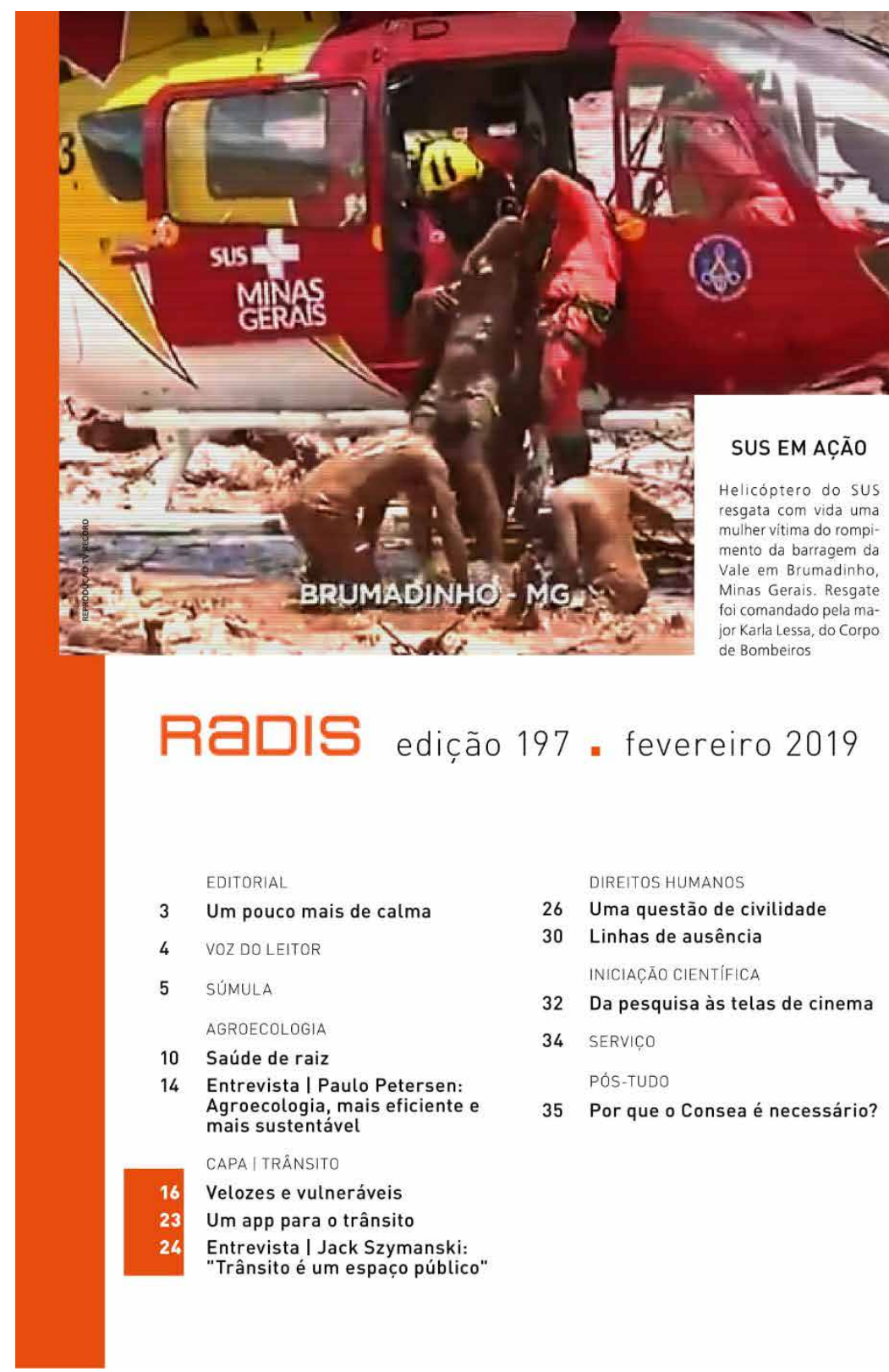

Figura 7 - Foto publicada na Revista Radis, destacando o papel do SUS em Brumadinho. Fonte: Radis. ${ }^{13}$

Essa conjuntura despertou o interesse de muitos estudiosos da saúde, particularmente de pesquisadores do Observatório de Clima e Saúde e do Laboratório de Informação e Saúde (LIS) do Instituto de Comunicação e Informação Científica e Tecnológica em Saúde (Icict) da Fundação Oswaldo Cruz (Fiocruz), no Rio de Janeiro, que, em nota técnica divulgada no dia $1^{\circ}$ de fevereiro, alertaram para o fato de que os milhões de metros cúbicos de lama tóxica e fétida que escorreram da barragem de rejeitos no Córrego do Feijão atingindo o Rio Paraopeba poderiam, a curto e médio prazo, interferir no quadro epidemiológico da região ao suscitar possíveis surtos de dengue, febre amarela, doenças infecciosas, além de interferir na saúde mental das pessoas direta ou indiretamente afetadas por essa tragédia. ${ }^{14}$

Segundo Diego Xavier e Christovam Barcellos, dois dos coordenadores do estudo, que teve como base uma pesquisa exploratória baseada nas primeiras evidências dessa tragédia e em comparação com tragédias anteriores, como a de Mariana, se em um primeiro momento a prioridade foi a de socorrer e contabilizar os mortos e os feridos, em um segundo momento, impunha-se a necessidade de acompanhar os possíveis casos de contaminação por metais pesados, principalmente daquelas pessoas que estavam trabalhando ou moravam próximas a área em que a barragem rompeu. Sintomas como diarreia, difteria, náuseas ou 
vômitos podem estar possivelmente relacionados com o contato que essas pessoas tiveram ou possam vir a ter com a lama tóxica ou com a água contaminada da região. ${ }^{14}$

Segundo ainda o estudo, a curto e médio prazo essas situações podem provocar também o incremento em doenças infectoparasitárias, principalmente pelo fato de que muitos serviços de interesse público tiveram de ser paralisados, como os de coleta de lixo cujo dejetos acumulados podem aumentar a presença de roedores e as possibilidades de as pessoas contraírem leptospirose e outras doenças. A nota técnica destaca também que muitos cursos d'água foram contaminados, deixando suas águas impróprias para o consumo humano e levando muitas pessoas a buscar soluções alternativas, como o armazenamento de água que, sem os devidos cuidados, pode criar condições potenciais para o surgimento de surtos de dengue e propiciar o surgimento do que os especialistas chamam de ecologia do vetor, ou seja, locais favoráveis à reprodução de mosquitos que provocam a dengue e outras doenças.

Entretanto, por mais mobilizado que esteve e ainda está o SUS local, muitos dos serviços prestados na área de saúde na zona de desastre, inclusive os de orientação, tiveram de ser suspensos por causa da interrupção das estradas de acesso, afetando aquelas pessoas que dependem de acompanhamento médico periódico, como os pacientes diabéticos, hipertensos ou pacientes renais.

Além disso, no campo da saúde mental, multiplicaram-se as demandas tanto por parte daqueles que perderam algum familiar, amigo ou colega de trabalho quanto por parte das crianças que, de uma hora para outra, se tornaram órfãos, afetando toda as suas respectivas redes de familiares. Até mesmo trabalhadores que estavam de folga no dia do rompimento se viram mentalmente perturbados com a morte dos amigos e certo remorso por terem escapado.

Em qualquer conversa superficial com os náufragos dessa tragédia, transpareciam diferentes e intensivas fontes de ansiedade, remorso ou compaixão em relação aos parentes e colegas mortos ou desaparecidos. Afinal, a maioria era originária das mesmas comunidades rurais ou da cidade de Brumadinho, onde formavam diferentes redes de vizinhança, parentesco, compadrio ou simples amizade.

O súbito rompimento dessas redes trouxe profundos desconfortos morais e psicológicos aos sobreviventes desnorteando-os.

E, se à medida que os corpos de algumas das vítimas dadas como desaparecidas iam sendo encontrados, trazendo certo alívio para as suas famílias, por outro, esta situação contrasta com a dor daqueles que continuam até hoje lutando desesperadamente para encontrar o corpo ou os restos mortais dos seus entes queridos que continuam desaparecidos.

O fato de não serem encontrados impedia a organização dos rituais fúnebres de despedida, mantendo suas imagens em uma espécie de limbo, impedindo o encerramento do ciclo da vida e fazendo com que muitos dos familiares dessas vítimas entrem em franco desespero, gerando inenarráveis casos de depressão e ansiedade.

Um anúncio de página inteira feito pela Vale no jornal Folha de S. Paulo informa que a Vale está "profundamente consternada com os efeitos do rompimento da barragem em Brumadinho"15 e que "continua empenhada no atendimento às necessidades das famílias dos atingidos". ${ }^{15} \mathrm{~A}$ seguir indica as ações que vem sendo realizadas para amenizar essa situação.

Em outra edição do mesmo jornal, mais uma vez ela se vale (sem trocadilhos) dessa tragédia para promover o seu ethos ao o informar que "a Vale, em manifestação de respeito às famílias atingidas pela tragédia de Brumadinho, formalizou nesta quarta-feira, 20/o2, um acordo sem precedentes na história do Brasil com autoridades e representantes da sociedade civil ${ }^{p 6}$ (o grifo é nosso).

A empresa anunciou que antecipará pagamentos emergenciais para a população residente até $1 \mathrm{~km}$ do leito do Rio Paraopeba, desde Brumadinho até a represa de Retiro Baixo, como resultado de acordo preliminar que prevê pagamentos mensais de 1 salário mínimo por adulto, 50\% de 1 salário mínimo por adolescente e $25 \%$ de 1 salário mínimo por criança, pelo período de 12 meses. 
Mas entre uma e outra audiência pública realizada na cidade ou nos distritos e comunidades do município, era nítido que o pacote de bondades ofertado pela Vale só funcionava em alguns casos e não levava em conta a dramaticidade das centenas de pessoas não necessariamente empregadas da empresa, mas que foram também profundamente atingidas ou prejudicadas por essa tragédia ou impedidas de manter suas atividades de subsistência. Quando elas procuraram a Vale, esbarraram no conceito parcial utilizado pela empresa sobre quem seriam os atingidos, considerando tão somente aqueles que morreram, desapareceram ou que perderam as suas casas no que ela chama de 'zona de autossalvamento'.

Como centenas de prejudicados não se enquadravam nesse critério restrito e parcial da empresa, eles se sentiram não apenas desamparados, mas profundamente revoltados, pois muitos perderam seus modos de subsistência, como muitos comerciantes, donos de pousada, agricultores, entre outros que não estão enquadrados dentro desse perímetro de autossalvamento.

Mesmo quando a Vale promete dar um salário mínimo para todo morador de Brumadinho durante um ano, ela dá a entender que se trata mais de uma liberalidade da empresa do que uma obrigação ou uma indenização às pessoas que ela prejudicou.

Quando essa tragédia completou um mês no dia 25/02, a população da cidade resolveu se manifestar promovendo uma passeata na cidade de Brumadinho com início na ponte do Rio Paraopeba, cujas águas avermelhadas testemunhavam o crime de lesa-humanidade perpetrado pela Vale afetando a vida de centenas de famílias, a economia e o meio ambiente do município.

Nessa oportunidade, muitos aproveitaram para reivindicar justiça e protestar contra a demagógica oferta feita pela Vale de doar um salário mínimo para cada morador do município durante doze meses, que foi considerado um simplório lampejo de remorso da empresa pela tragédia que causou a Brumadinho.

Alguns chegaram a classificar como risíveis, senão desrespeitosas, as tentativas da empresa em se justificar diante da tragédia, tratando-a como um simples acidente de percurso, sem levar em conta as consequências que trouxe para o município e a sua população. A começar pelo desmantelamento que provocou na complexa rede produtiva econômica do município que será afetada diante do desemprego, desvalorização de muitas propriedades rurais e desativação de pequenos e médios empreendimentos, principalmente aqueles instalados nas proximidades da região por onde escorreu a lama tóxica da barragem de rejeitos da empresa, matando e destruindo tudo o que encontrou pelo caminho.

Diante disso tudo, muitos moradores locais, ainda perplexos, passaram a remoer a memória tentando encontrar alguma similitude entre essa tragédia e outros acidentes na longeva história da mineração no município que remonta a 1910, quando foi dado o início da 'corrida do ferro' no Brasil, principalmente no Quadrilátero Ferrífero, em que diversas potências estrangeiras e empresas nacionais passaram a comprar as terras onde se localizavam as principais jazidas de minério de ferro, a principal matéria-prima que iria garantir a industrialização das grandes potências daquela época, cujo processo havia sido iniciado no final do século anterior. Aliás, foi exatamente em 1911, um ano depois de iniciada essa corrida, que a Companhia Metallurgica, testa de ferro do capital inglês e francês, comprou a jazida Inhotim, de José de Abreu, com a finalidade de explorar o minério de ferro naquele local com base no pressuposto de que a Constituição de 1891 garantia aos proprietários da terra toda a riqueza que fosse encontrada em seu subsolo. Embora essa jazida só entrasse em operação na década de 1930, outras jazidas no município, como a da empresa paulista Souza Noschese, passaram a funcionar, ainda que de forma precária depois de 1920.

O auge da exploração minerária no Vale do Paraopeba e em Brumadinho só se daria após a entrada do Brasil na Segunda Guerra Mundial quando a produção foi intensificada para atender o mercado industrial brasileiro e os países aliados em guerra contra a Alemanha.

Em todo esse período, não houve registros de graves acidentes na mineração, embora fosse uma época de assistência médica e social precária e poucas noções de risco ou de ações sobre prevenção de acidentes 
ou de possíveis tragédias que pudessem, ainda que timidamente, ser comparadas com o que aconteceu em Mariana, em 2015, e agora em 2019 no Córrego do Feijão.

Ademais, antes de acontecer a atual tragédia provocada pelo rompimento da barragem da mina do Córrego do Feijão, o sonho de qualquer trabalhador da região era o de trabalhar na Vale. Não obstante ser uma empresa extremamente exigente em relação à segurança dos empregados, tinham ali a garantia de bons salários, assistência social, psicológica e bons planos de saúde, imagens estas que, neste momento, estão desvanecidas sob a lama e misturadas ao sangue dos cerca de 300 mortos que hoje atingem as águas do Rio Paraopeba.

Essa situação provocou na sociedade civil a formação ou o fortalecimento de públicos críticos que estão organizando e intensificando a luta dos vários grupos atingidos por essa tragédia, como o movimento 'Eu Luto, Brumadinho Vive' que reúne organizações não governamentais, entidades locais e moradores de Brumadinho, na Região Metropolitana de Belo Horizonte (RMBH) (Figura 8). Esses atores se uniram para dar apoio aos atingidos pelo rompimento da barragem da Mina Córrego do Feijão, contando com o apoio do Movimento dos Atingidos pelas Barragens (MAB), que atua em âmbito nacional.

Também várias instituições como a Universidade Federal de Minas Gerais, a Pontifícia Universidade Católica de Minas, o Ministério Público, a Ordem dos Advogados do Brasil, a mídia nacional e local, várias congregações religiosas, principalmente a Igreja Católica, assim como as redes sociais, estão atuando ativamente e se organizando para catalisar as diferentes movimentações sociais a favor das vítimas dessa tragédia no município e para que ela não se repita mais em nenhum lugar.

A proposta desses movimentos é a de fazer a ponte entre vítimas e familiares de mortos e desaparecidos com o poder público e a Vale, buscando a reparação de danos ambientais, cíveis e trabalhistas, assim como a responsabilização criminal pela tragédia através de plano de ação com base na análise de medidas judiciais e administrativas.

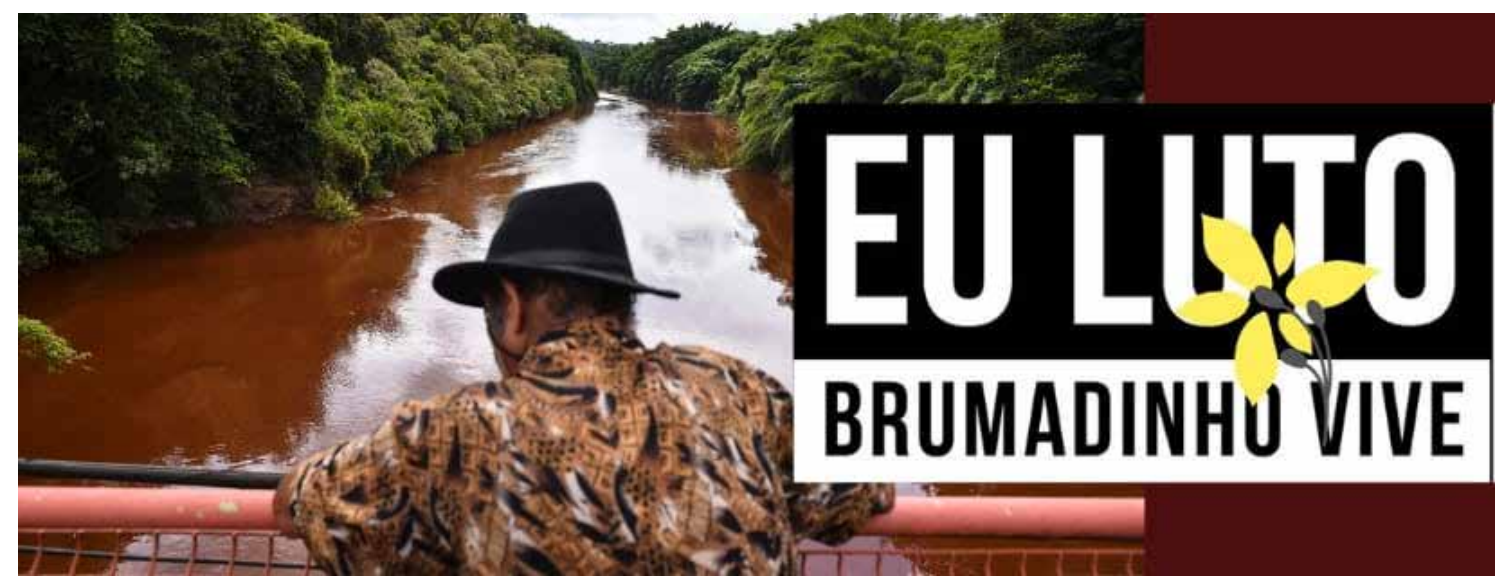

Figura 8 - Ponte sobre o Rio Paraopeba com suas águas avermelhadas pela lama da Vale em Brumadinho Fonte: Eu Luto, Brumadinho Vive (2019). ${ }^{\vee}$

Outras movimentações sociais convergentes com essa proposta estão acontecendo com frequência no município. Uma delas foi a reunião realizada no dia 24 de fevereiro em que produtores rurais, comerciantes, empreendedores, associações comunitárias, representantes de cerca de 40 comunidades rurais, quilombolas e de condomínios da região se reuniram na Escola Municipal Josias José Araújo, em Palhano, interior de Brumadinho, para protestar contra o isolamento a que foram submetidos por causa do fechamento da única estrada que dava acesso ao centro de Brumadinho, por Alberto Flores, que foi encoberta pela lama, como nos informa Marciano Reis Mariano em artigo publicado no jornal Circuito, de Brumadinho. ${ }^{17}$

v Capa da página Eu Luto, Brumadinho Vive. 
Segundo o autor, durante essa reunião (Figura 9) foram discutidos diversos problemas enfrentados pelos moradores, como os cortes de serviços essenciais na área da saúde e educação, a falta de atendimento e suporte aos comerciantes, ao setor turístico e aos produtores rurais que estão com dificuldades de escoar a produção, além de acordos judiciais que estão sendo firmados pela justiça com a Vale, sem a participação das entidades representativas e de moradores das comunidades de Brumadinho.

Um documento oficial para ser encaminhado ao Ministério Público de Minas Gerais foi elaborado com diversas reivindicações divididas entre emergenciais, de curto prazo e médio prazo. As reivindicações mais imediatas estão listadas a seguir:

Emergenciais: 1) liberação imediata da Estrada de Alberto Flores à sede do município; 2) implantação de ambulâncias com unidades de terapia intensiva e desfibriladores externos automáticos, com profissionais capacitados em Aranha, Piedade do Paraopeba, São José do Paraopeba e Suzana; 3) implantação de caixa eletrônico 24h em Aranha, com acompanhamento da Polícia Militar, para facilitar a vida dos produtores e comerciantes; 4) retomada dos horários de ônibus de todas as linhas das comunidades para a sede; 5) disponibilização por parte das empresas de ônibus coletivo de espaços nos veículos, para que moradores de comunidades mais distantes possam levar alimentos comprados na sede, já que muitas comunidades distantes não têm comércio próprio.

Curto Prazo: 1) convocação imediata de uma Audiência Pública consultiva e deliberativa, marcada no dia 10 de março, às 9h3o, a ser realizada no Distrito de Aranha, para ouvir os moradores das comunidades do interior, também atingidos diretamente pelo crime da Vale; 2) que na comissão de deliberação e gestão a ser criada pelos Ministérios Públicos Estadual e Federal e Defensoria Pública, haja representação paritária dos atingidos de Brumadinho, incluindo os produtores rurais, prestadores de serviços, comerciantes e associações locais, com atuação em Brumadinho; 3) que sejam esclarecidas publicamente as atribuições e critérios de escolha e forma de prestação de contas das assessorias técnicas, com demonstração de resultados; 4) que sejam criados mecanismos de fortalecimento das associações comunitárias locais; 5) que a Vale seja obrigada a apresentar um Plano de Recuperação de áreas degradadas (PRAD) e um Projeto Técnico de Reconstituição da Flora (PTRF), ações imediatas e mediatas estabelecidas em audiência pública; 6) que sejam estabelecidos planos de recuperação e reconstituição imediata da imagem turística de Brumadinho, com apresentação em audiências públicas para esse fim, ouvindo todo o segmento; 7) que os órgãos Agência Nacional de Mineração (ANM) e Secretaria Estadual de Meio Ambiente (SEMAD) façam uma auditoria e análises nos documentos e laudos apresentados pela empresa Vallourec, sobre a Barragem Santa Bárbara, localizada em Piedade do Paraopeba e que sejam apresentados os resultados em audiência pública; 8) que seja instituída a Comissão Parlamentar Mista de Inquérito (CPMI) na Câmara dos Deputados; 9) que também sejam criadas Comissões Parlamentares de Inquérito (CPIs) no âmbito municipal e estadual; 10) que sejam tomadas providências imediatas na reparação de danos aos comerciantes, produtores rurais, prestadores de serviços locais e que seja revisto o raio indenizatório estabelecido pela Vale. ${ }^{17}$ 


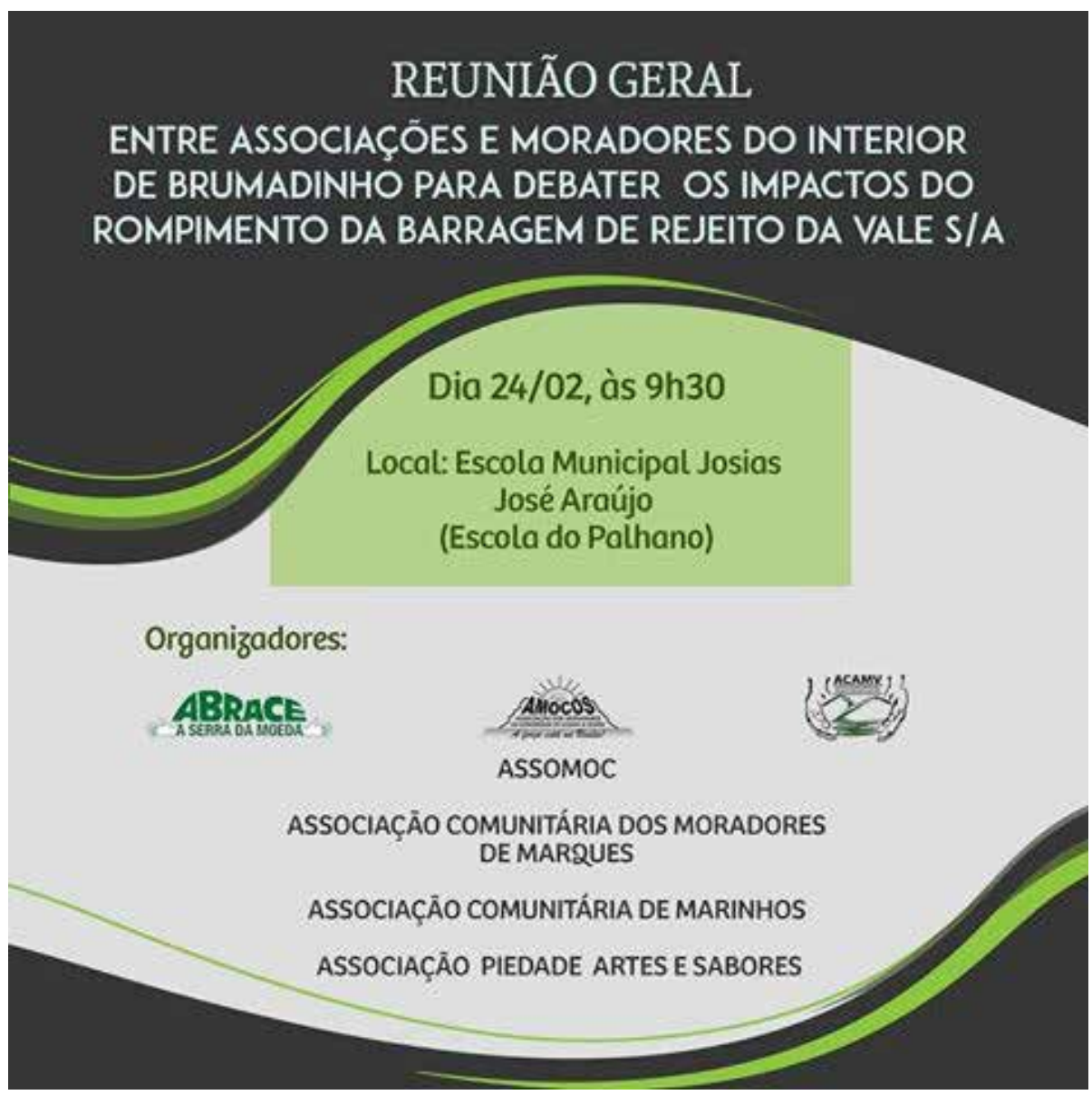

Figura 9 - Sociedade debate impactos do rompimento da barragem de rejeitos da Vale

Fonte: Assomoc, Associação Comunitária dos Moradores de Marques, Associação Comunitária de Marinhos, Associação Comunitária de Piedade do Paraopeba. ${ }^{\text {vi }}$

\section{Contextualizando as causas da tragédia}

Possivelmente o que aconteceu nos municípios de Mariana e Brumadinho e em outros lugares do mundo está atrelado tanto à intensificação quanto às formas de gestão dos empreendimentos de mineração que, para se manter em um mercado cada vez mais competitivo, investem em tecnologia impondo novos padrões de extração e de beneficiamento do minério com a finalidade de incrementar seus resultados para a rede de interesses que giram no seu entorno, principalmente os variados grupos de acionistas a quem a empresa presta contas, em especial sobre os resultados financeiros de suas atividades. A convergência dessas questões é o que permite nos conferir certa inteligibilidade a essas tragédias cujos contornos vão sendo gradativamente delineados à medida em que fluem as conversações sociais, a ação da mídia (nacional e local), a discussão nas redes sociais e à medida em que vários documentos da empresa vão sendo publicamente desvelados ${ }^{\text {vii. }}$.

Com isso, aos poucos vamos tendo a certeza de que o que aconteceu tanto em Mariana quanto em Brumadinho não foram situações aleatórias ou simples desastres ambientais e sim o resultado trágico de um modelo de gestão e de administração das atividades extrativistas no Brasil e no mundo que ostentam um extenso e crescente rol de desastres ambientais com graves e indescritíveis consequências para a fauna, a flora e a sociedade.

vi Convocatória pública das associações comunitárias e de outras organizações da sociedade civil de Brumadinho para discutir e debater os impactos do rompimento da Barragem de Rejeitos da Vale e que circulou nas redes sociais do município.

vii A Vale foi criada em 1942, sendo estatizada em 1997. Atualmente o seu controle está dividido através dos seguintes grupos de acionistas: Investidores brasileiros (13\%), BNDESpar (7\%), Mitsui Co (5\%), Bradespar (6\%), Litel (21\%), investidores estrangeiros (NYSE e Bovesp), $48 \% .18$ 
Isso nos leva a constatar também que tal modelo, no qual se inclui a Vale, está profundamente atrelado a e enraizado em complexas teias de poder e de interesses econômicos que envolvem bancos, grandes escritórios de advocacia, analistas, consultores e uma miríade de investidores, institucionais ou não, que cobram e pressionam seus dirigentes por resultados financeiros positivos gerados pelas suas atividades extrativistas. Essas teias de comando e de interesse pressionam seus dirigentes de cima para baixo a fim de garantir resultados financeiros positivos que serão transformados em cobiçados e polpudos dividendos para os seus acionistas.

Para isso se faz necessário incrementar, modernizar e fazer com que as cadeias de produção e de produtividade da empresa funcionem de maneira que façam crescer o valor do empreendimento no mercado de ações satisfazendo os seus acionistas.

O problema é que a pressão emanada desse modelo de gestão é tão forte que acaba se transformando em um fator de insegurança e de risco, como possivelmente aconteceu em Mariana, Brumadinho e alhures, pois segurança e ausência de riscos, embora desejados, não apenas custam caro, mas também podem comprometer a linha de produção e o resultado final desejado pelo empreendimento.

Embora não se possa dizer que haja uma ilação objetiva e direta entre esse modelo de gestão e essas duas tragédias, à medida que as informações vão sendo reveladas pelos dirigentes das empresas, pela mídia e pelas autoridades aos poucos vamos concluindo que os riscos de rompimento da barragem do Córrego do Feijão não eram desconhecidos e nem que poderiam ser fruto de causas naturais. Os relatórios das empresas de consultoria, o depoimento dos técnicos da empresa e os trabalhos de vistoria apontavam, ainda que de forma inconclusiva, que os riscos de rompimento de fato existiam e que sua solução demandaria, além de alto custo, a paralisação de boa parte das atividades da empresa na Mina do Córrego do Feijão.

Possivelmente foram essas as variáveis que fizeram com que a empresa mantivesse também várias instalações administrativas, estacionamento e refeitório bem abaixo da barragem de rejeitos ao invés de transferi-las para zonas de segurança.

A noção sobre os perigos de rompimento dessa barragem era tão clara que o Plano de Emergência da empresa projetou várias situações hipotéticas sobre as consequências caso a barragem, construída em 1976, se rompesse: estimou número de mortos e calculou o montante de indenizações a pagar. Embora essas instalações remontassem à época da Ferteco, empresa anterior que explorou a jazida de minério de ferro do Córrego do Feijão, e essa barragem estivesse desativada há três anos, o risco de rompimento sempre existiu, mas, ao que tudo indica, pouco foi feito para efetivamente evitá-lo.

Isto nos leva a perguntar se o rompimento dessa e de outras barragens poderiam ter sido evitados?

Quem nos responde é Mami Muzutori através de artigo publicado no jornal Folha de S. Paulo ${ }^{19}$. Segundo o autor, em 2001 a Organização das Nações Unidas (ONU), por meio da Comissão Internacional para Grandes Barragens, emitiu o relatório "Barragens de Resíduos: Riscos de Perigosas Ocorrências” depois de examinar 221 rompimentos, concluindo que todos poderiam ter sido evitados desde que fossem tomadas algumas das precauções recomendadas por esse documento.

Apesar de o relatório ser de 2001, sabe-se que pouca coisa foi feita de lá para cá para prevenir esse tipo de desastre, provavelmente por causa dos custos que isso acarreta e do comprometimento que gera para a produção e a produtividade dos empreendimentos, como mencionamos anteriormente. Ademais, governanças corruptas ou compassivas impedem a existência de um olhar regulatório mais adequado sobre essas instalações, aumentando-se as possibilidades de tragédias como as que aconteceram em Mariana e Brumadinho.

No Brasil, infelizmente, a sociedade civil é bastante fragilizada diante do Estado e dos interesses econômicos e, mesmo quando se manifesta criticamente diante da indústria da mineração, como é o caso em Brumadinho, seja durante as fases de licenciamento ambiental, seja, durante o seu funcionamento, não consegue transformar seus queixumes em práticas de boa governança, favorecendo o interesse público. 
Ademais, tragédias como as de Mariana e Brumadinho têm como vítimas diretas a população que vive no entorno ou nas proximidades desses empreendimentos; ainda que nem todas as pessoas tenham ligação direta com as atividades mineradoras, são diuturnamente afetadas por elas, assim como ocorre com os biossistemas naturais extremamente afetados quando acontecem essas tragédias. No caso de Mariana, toda a população da Bacia do Rio Doce até o litoral do Espírito Santo pagou um alto custo quando se viu impedida de exercer a pesca ou de consumir a água do rio, o que acarretou incalculáveis perdas econômicas, ambientais e humanas nos municípios que, direta ou indiretamente, foram afetados pela tragédia.

Essas situações formam uma espécie de bomba-relógio anunciando as possibilidades de novas tragédias, como nos lembrou Mathias Spector ${ }^{20}$ ao denunciar a existência de uma mina de urânio desativada em Poços de Caldas (MG) que esteve em operação entre 1982 e 1995. O urânio era usado como combustível de Angra 1, em pesquisas no setor nuclear e num esquema de comércio de compensação junto ao Iraque. Nesse artigo, Spector denuncia que as atividades da mina foram encerradas, mas não houve a descontaminação das áreas exploradas, nem foram seguidos os padrões que garantiriam a preservação ambiental e a segurança das populações afetadas. Segundo o autor, o sistema que acumula os rejeitos está seriamente comprometido e com infiltração, aumentando o risco de ruptura. Caso essa barragem de rejeitos se rompa, milhões de toneladas de rejeitos radioativos podem trazer consequências incalculáveis para a região.

As causas dessas e de outras tragédias semelhantes, lembra-nos Henri Acselrad ${ }^{21}$, está naquilo que o sociólogo alemão Ulrich Beck (1944-2015) chamou de "irresponsabilidade organizada"22 para expressar de que maneira vem se dando a submissão sistemática dos poderes públicos a interesses privados fortemente dependentes de tecnologias perigosas e intensivas em espaços de recursos naturais, fazendo com que tragédias como esta da Barragem do Córrego do Feijão não possam ser consideradas simples desastres técnicos, mas sim desastres políticos, pois fatos dessa natureza colocam em discussão toda a estrutura de regulação dos grandes empreendimentos fazendo ruir a credibilidade dos processos de licenciamento a que são submetidos ${ }^{21}$.

Tais mudanças fazem parte do Antropoceno ${ }^{23}$, uma nova era geológica que se caracteriza por ser um período marcado pela atuação do ser humano como principal agente das mudanças ocorridas no planeta, em uma escala inédita ${ }^{\text {viii. }}$

O conjunto dessas questões nos leva a crer que devemos pensar em uma nova ética do desenvolvimento econômico que não pode continuar a ser entendido apenas como desenvolvimento das atividades produtivas sem levar em conta a dimensão humana, a natureza e o meio ambiente dentro dos princípios da sustentabilidade tão apregoados publicitariamente pelas empresas e tão pouco seguidos pelas suas práticas efetivas de gestão e de produção. Tudo isso nos leva a crer que este modelo de desenvolvimento está colocando em risco a existência não apenas do meio ambiente, mas também de toda a sociedade e do próprio planeta, seja por razões climáticas, bélicas ou simplesmente por causa do esgotamento de muitos de seus recursos vitais, como a água e o ar que respiramos. É o que Ulrich Beck chamou de efeito bumerangue, ou seja, o efeito indesejado que muitas das soluções econômicas e tecnológicas que adotamos na contemporaneidade provocam na vida social e no planeta que, se por um lado, trazem respostas positivas a muitos de nossos problemas, por outro lado se voltam contra nós trazendo incalculáveis riscos tanto para a nossa segurança social, ambiental quanto ontológica. ${ }^{23}$

Esse pensamento reforça a frase lapidar do sociólogo Boaventura de Souza Santos quando afirma que a sociedade moderna foi pródiga em acumular muito conhecimento e muita técnica, mas pouco prudente em acumular sabedoria, lembrando a phronesis aristotélica da arte do bem decidir. ${ }^{24}$

viii "O termo foi criado em 2002 por um dos três vencedores do Prêmio Nobel de Química de 1995, o holandês Paul Crutzen, ao considerar a influência humana no funcionamento do planeta tão significativa a ponto de justificar a entrada do homem em uma nova era geológica construída por ele." ${ }^{23}$ 
É neste contexto que também testemunhamos desde a década de 1980 o desmonte das agências ambientais em nível federal e estadual através do Congresso Nacional e das assembleias legislativas que convergem para aprovar leis que atendem mais aos interesses da indústria da mineração do que os da sociedade através da promiscuidade que ambos mantêm com alguns políticos que conformam a chamada Bancada da Lama cujas campanhas eleitorais são financiadas pelas mineradoras.

Tais deputados são bem atuantes nos assuntos do setor da mineração propondo mudanças em textos que já resultaram em retirada de fiscalização, além de ocuparem cargos chave em comissões que influenciam o que passa na Câmara.

Ademais, como nos lembrou bem Arister Chimeli ${ }^{25}$, em diversas regiões do mundo onde recursos naturais geram grandes receitas, tornou-se comum a predominância de instituições fracas de proteção ambiental. Países em que predomina a captura da riqueza nacional por grupos de interesse no lugar de instituições que promovem ganhos coletivos encontram sérias dificuldades para se desenvolverem. As leis são vagas, têm aprovação lenta, o monitoramento formal e informal é deficiente e a punição por danos é branda ou ineficaz.

A tudo isso se soma a promiscuidade entre fiscalizador e fiscalizado que também concorre para transformar esse processo em uma espécie de jogo de compadres. Não é possível conceber que a empresa que atestou a segurança da barragem que se rompeu em Brumadinho no dia 25/o1 tenha prestado também serviços de consultoria para a Vale, o que, no mínimo, configuraria conflito de interesses.

\section{Conclusão}

Pelo exposto, fica claro que o que aconteceu em Brumadinho foi muito mais um crime do que um simples desastre ou um acidente de percurso do setor de mineração, pois como declararam os próprios representantes da Vale, os sinais de perigo de rompimento da barragem do Córrego do Feijão estavam dados e consubstanciados tanto nos relatórios de fiscalização e de consultoria contratados pela empresa quanto em seus próprios relatórios e que, ao que tudo indica, foram ignorados.

Por essas e outras razões anteriormente relatadas é que não adianta o setor investir pesadamente na comunicação para construir uma imagem positiva sobre a importância de suas atividades se não levar em conta as questões substantivas que envolvem o interesse da sociedade e as condições ambientais adversas que enfrentamos e teremos de enfrentar e que, se forem ignoradas, podem colocar em xeque a própria vida no planeta.

Isso impõe não apenas a mudança de mentalidade em relação aos atuais modelos de desenvolvimento econômico, mas também a necessidade de rever os modelos informacionais e comunicacionais desses empreendimentos mais voltados para promover a semântica do eufemismo do que para promover o efetivo diálogo social que, para assim ser considerado, deveria ser mediado pela alteridade e pela responsabilidade coletiva calcada em valores éticos.

\section{Referências}

1. Movimento dos Atingidos por Barragens. Dossiê O Lucro não Vale a Vida: análise do MAB sobre o crime da Vale em Brumadinho [Internet]. 2019 [citado em 2019 mar. 19]. Disponível em: https://issuu.com/ mabnacional/docs/cartilha-brumadinho-2019-web/2

2. Verón E. A produção de sentido. São Paulo, Cultrix; 1980.

3. Giddens A. As consequências da modernidade. São Paulo: Editora Unesp; 1997.

4. Oliveira IL, Joía L. Ethos e imagens: articulações nos discursos organizacionais. In: França VRV, Simões P, organizadoras. O Modelo praxiológico e os desafios da pesquisa em comunicação. Porto Alegre: Sulina; 2018. p. 175-93. 
5. Notícias Vale (Vale). 2018 jul.

6. $\quad$ Notícias Vale (Vale). 2018 mar.

7. Notícias Vale (Vale). 2018 jun.

8. $\quad$ Notícias Vale (Vale). 2018 mar.

9. $\quad$ Notícias Vale (Vale). $2018 \mathrm{dez}$

10. Notícias Vale (Vale). 2018 nov.

11. Mariano R. Traídos pela barragem: eles dedicaram a vida à Vale e morreram engolidos pela lama. Interesse de Minas [Internet]. 2019 [citado em 2019 fev. 18]. Disponível em: http://interessedeminas. com.br/traidos-pela-barragem-eles-dedicaram-a-vida-a-vale-e-morreram-engolidos-pela-lama/

12. Qualidade da água do rio Paraopeba em Brumadinho é considerada ruim. SOS Mata Atlântica [Internet]. 2019 [citado em 2019 fev. 18]. Disponível em: https://www.sosma.org.br/107805/qualidade-da-aguario-paraopeba-em-brumadinho-e-considerada-ruim/

13. [Sumário]. Radis. Rio de Janeiro. 2019;197:2.

14. Romão A, Froes C, Barcellos C, Silva DX, Saldanha R, Gracie R, et al. Avaliação dos impactos sobre a saúde do desastre da mineração da Vale (Brumadinho, MG) [Internet]. Rio de Janeiro: Observatório de Clima e Saúde; 2019 [citado em 2019 fev. 18]. Disponível em: https://www.icict.fiocruz.br/sites/www. icict.fiocruz.br/files/Relat Brumadinho impacto Saude 01022019.pdf

15. Comunicado Vale. Folha de S. Paulo, 2019 fev. 24:A13.

16. Vale Informa. Folha de S. Paulo. 2019 fev. 21:A15.

17. Mariano MR. Associações e Moradores de Brumadinho se reúnem para discutir Impactos, após Rompimento da Barragem da Vale. Circuito Notícias. 2019 mar.:(306):9.

18. Vale. Investidores: composição acionária [Internet]. [citado em 2019 dez. 10]. Disponível em: http:// www.vale.com/brasil/PT/investors/company/shareholding-structure/Paginas/default.aspx

19. Muzutori M. É hora de a mineração ter política de acidente zero. Folha de S. Paulo [Internet]. 2019 fev. 13 [citado em 2019 mar. 18]. Disponível em: https://www1.folha.uol.com.br/opiniao/2019/02/e-hora-dea-mineracao-ter-politica-de-acidente-zero.shtml

20. Spector M. Barragem de rejeitos radioativos acende alerta no setor nuclear. Folha de S. Paulo [Internet]. 2019 fev. 21 [citado em 2019 mar. 18]. Disponível em: https://www1.folha.uol.com.br/colunas/ matiasspektor/2019/02/barragem-de-rejeitos-radioativos-acende-alerta-no-setor-nuclear.shtml

21. Acserald H. Descaminhos tropicais do antiambientalismo. Folha de S. Paulo. 2008 dez. 02: Caderno Ilustríssima:09.

22. Beck U. Sociedade de risco: rumo a uma outra modernidade. São Paulo: Ed. 34; 2010.

23. Carvalho DCC. A (in) sustentabilidade na comunicação no licenciamento ambiental de grandes empreendimentos no Brasil: processo comunicacional e organizacional na instalação de uma mina de ferro no Pará [Tese]. Rio de Janeiro: Fiocruz; 2019.

24. Santos BS. Introdução a uma ciência pós-moderna. Rio de Janeiro: Graal; 1989.

25. Chimeli A. A sombra do Brasil Velho. Folha de S. Paulo. 2019 fev. 03: Caderno Ilustríssima:04. 